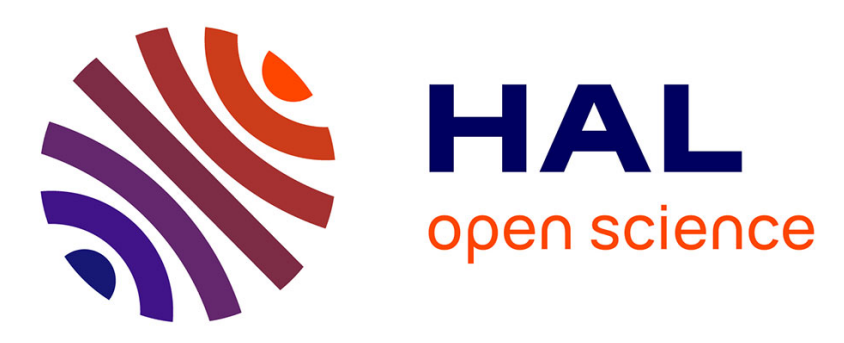

\title{
Grain size distributions of fault rocks: a comparison between experimentally and naturally deformed granitoids.
}

Nynke Keulen, Renée Heilbronner, Holger Stünitz, Anne-Marie Boullier, Hisao Ito

\section{To cite this version:}

Nynke Keulen, Renée Heilbronner, Holger Stünitz, Anne-Marie Boullier, Hisao Ito. Grain size distributions of fault rocks: a comparison between experimentally and naturally deformed granitoids.. Journal of Structural Geology, 2007, 29, pp.1282-1300. 10.1016/j.jsg.2007.04.003 • hal-00194259

\section{HAL Id: hal-00194259 \\ https://hal.science/hal-00194259}

Submitted on 6 Dec 2007

HAL is a multi-disciplinary open access archive for the deposit and dissemination of scientific research documents, whether they are published or not. The documents may come from teaching and research institutions in France or abroad, or from public or private research centers.
L'archive ouverte pluridisciplinaire HAL, est destinée au dépôt et à la diffusion de documents scientifiques de niveau recherche, publiés ou non, émanant des établissements d'enseignement et de recherche français ou étrangers, des laboratoires publics ou privés. 
2

3 Grain size distributions of fault rocks: a comparison between experimentally and

4

5

6 7

\section{naturally deformed granitoids.}

Nynke Keulen $^{1 *}$, Renée Heilbronner ${ }^{1}$, Holger Stün itz ${ }^{1}$, Anne-Marie Boullier ${ }^{2}$, Hisao Ito ${ }^{3}$

${ }^{1}$ Geological Institute, University of Basel, Bernoullistrasse 32, CH-4056 Basel, Switzerland

${ }^{2}$ Université Joseph Fourier, Laboratoire de Géophysique Interne et Tectonophysique, UMR CNRS 5559, Maison des Géosciences, BP 53, 38041 Grenoble Cedex 9, France

${ }^{3}$ Center for Deep Earth Exploration, Japan Agency for Marine-Earth Science and Technology 3173-25 Showa-machi, Kanazawa-ku, Yokohama, Kanagawa 236-0001, Japan

* corresponding author:

nynke.keulen@unibas.ch

tel. $+41-61 / 2673609$

fax. $+41-61 / 2673613$

\section{Nynke Keulen}

Geological Institute, University of Basel

Bernoullistrasse 32

CH-4056 Basel

Switzerland 
Grain size distributions of fault rocks: a comparison between experimentally and nat urally deformed granitoids.

Nynke Keulen, Renée Heilbronner, Holger Stünitz, Anne-Marie Boullier, Hisao Ito

\section{Abstract}

We have investigated the grain size distribution (GSD) of granitoid fault rock by comparing experimentally produced gouge with fault rock from the Nojima Fault Zone. Triaxial experiments were carried out on wet and dry intact samples of Verzasca Gneiss at $\mathrm{T}=300$ and $500^{\circ} \mathrm{C}, \mathrm{P}_{\mathrm{c}}=500$ and $1030 \mathrm{MPa}, \varepsilon=0.013-1.6 \times 10^{-4} \mathrm{~s}^{-1}$. The GSD has been determined from SEM-micrographs and is characterized by the slope, $\mathrm{D}$, of its $\log$ (frequency)-log(radius) histogram. The GSD is not fractal; we observe two slopes for all GSDs. The larger grains in experimentally deformed samples have a Dvalue, $\mathrm{D}_{>}$, of 2.04 and 2.26 for feldspar and quart gouge. Cracked grains yield values of $\mathrm{D}=1.5-1.6$. Increasing the confining pressure or temperature decreases the D-value. For grains smaller than $\sim 2$ $\mu \mathrm{m}$ another $\mathrm{D}$-value, $\mathrm{D}_{<}$, of $0.9-1.1$ is observed. The grain radius at the slope chan ge, $\mathrm{r}_{\mathrm{K}}$, corresponds to the grinding limit of quartz, so that $r_{K}$ probably represents a change in the dominant comminution mechanism from grinding to attrition-processes. The GSD obtained from deformation experiments agrees well with results for the Nojima Fault Zone: $\mathrm{D}_{>}=2.02$ for gouge and 1.64 for cracked grains; $\mathrm{D}_{<}=0.97$. Grain size reduction in fault zones develops by a two-stage process: rupturing creates cracked grains; further displacement of fragments causes further comminution by wear and attrition. Cracked grains have been used to calculate the surface energy associated with faulting; it follows that this energy forms a small fraction in the total energy-budget of earthquakes.

Keywords: faulting, granite, gouge, grinding, surface density, power-law distribution 


\section{Introduction}

\subsection{Overview}

Major fault zones and earthquakes in the upper crust typically develop highly localized zones of deformation. At the macroscopic scale, faults usually appear as narrow, highly deformed zones or networks embedded in wide damage zones of relatively low deformation.

Observation s on natural fault zones have shown that this localization of deformation along faults occurs both in space and time (e.g. Mitra, 1993; Faulkner et al., 2003; Wilson et al., 2003). Most of the displacement takes place in very narrow zones with in the gouge of typically a few to $100 \mu \mathrm{m}$ wide, leaving the rest of the gouge inactive (e.g. Wibberley and Shimamoto, 2005; Chester et al., 2005; Ma et al., 2006). Bos et al. (2000) have made this same observation for laboratory experiments on halite.

Within these narrow deformation zones gouge with a wide ran ge of grain sizes has been produced (e.g. Storti et al., 2003, Boullier et al., 2004a). At the microscopic scale, the fault rock consists of cataclasite or gouge with properties that change as a function of time and space. Displacement on a fault zone causes the evolution from a thin fracture to a wider gouge zone. The microstructures of the fault rocks influence and reflect the mechanics of faulting, i.e., earthquakes. For example, evidence for coseismic hydraulic fracturing (Boullier et al., 2004b) or for a change in the frictional properties of faults resulting from their grain shape (Mair et al., 2002) has been obtained through microstructural studies. Despite experimental data and field observations on gouge, the properties of fault rock and the evolution of cracked grains to gouge still remain rather poorly understood. 85

6

\subsection{Fault rocks}

A number of definitions for fault rocks can be found in the literature (e.g. Sibson, 1977;

White, 1982; Wise et al., 1984; Chester et al., 1985; Schmid and Handy, 1991). Usually, cohesive and noncohesive fault rocks are attributed to cataclasis, a process involving fracturing, frictional sliding, dilatancy, and rigid body rotation between grain fragments, grains, or clusters of grains. Sibson (1977) has defined gou ge as a cataclastic rock without cohesion; the cohesive rock is called cataclasite. Many cohesive cataclasites in nature are 
thought to be the product of syn- or post-tectonic healing processes (Schmid and Handy, 1991).

In this study, however, we will distinguish different fault rocks on the basis of microstructures rather than inferred mechanical properties (see Heilbronner \& Keulen, 2006). We will use the term "cracked grains" for angular fragments that have fractured without much displacement (such that the original geometrical relationship of the fragments can still be recognized). The term "gouge" will be used for more highly deformed fault rocks where the grains are more rounded and the original spatial relationsh ip between the fragments is lost. The term "fault rocks" thus applies to both cracked grains and gouge.

\subsection{Grain size d istributions}

A large number of studies has been dedicated to measuring and analyzing grain size distributions of fault rocks (e.g. Mitra, 1993; Blanpied et al., 1995; Lin, 1999; Bos et al., 2000; Stewart et al., 2000; Kato et al., 2003). The grain size distribution (GSD) is considered as an important parameter for the characterization of the gouge (e.g. Sammis et al., 1987; Marone and Scholz, 1989; Hadizadeh and Johnson, 2003; Wilson et al., 2005; Chester et al., 2005). Within a certain size range the GSD may be self-similar (scale invariant) and in this case can be described by a power-law relationship (Mandelbrot, 1982). The slope of some power-law distributions, D, is called the fractal dimension (Turcotte, 1992; Korvin, 1992, and references in both). This D-value has often been used to compare the GSD of natural earthquake and fault zones, like the San Andreas Fault zone (e.g. Anderson et al., 1980; Blenkinsop, 1991), the Moine Thrust (Blenkinsop and Rutter, 1986) or fault systems in Japan (Monzawa and Otsuki, 2003; Otsuki et al., 2003) with fault rocks derived from experiments (e.g. Marone and Scholz, 1989; Morrow and Byerlee, 1989; Amitrano and Schmittbuhl, 2002).

For the measurements of the GSD, several different methods have been used (see Table 1). The most classical one, originating from sedimentology, is sieving. By this method a distribution of mass against size is obtained (Anderson et al., 1980; Sammis et al., 1986). Other studies have used the Coulter counter (An and Sammis, 1994; Amitrano and Schmittbuhl, 2002; Wilson et al., 2005) or optical microscopy on thin sections (Biegel et al., 1989; Monzawa and Otsuki, 2003); these methods provide a description of the GSD in terms 
of frequency versus grain size. A disadvantage of sieving and the use of light microscopes is that the size of smallest detectable grains is $\sim 2 \mu \mathrm{m}$ (Table 1).

An easy way to measure the sizes of the grains smaller than $2 \mu \mathrm{m}$ is scanning electron microscopy (SEM), as was done by Sammis et al. (1987) and Shao and Zou (1996), but in their samples no small grains were observed. Olgaard and Brace (1983), Yund et al. (1990), and Chester et al. (2005) found grains as small as $15-50 \mathrm{~nm}$ with the TEM, but the TEM is unsuitable for measuring large numbers of grains necessary to obtain a size distribution. Wilson et al. (2005) used a Coulter counter and measured grains of $40 \mathrm{~nm}$ to $300 \mu \mathrm{m}$. Nevertheless, the frequency distribution of grains sized between $30 \mathrm{~nm}$ and $2 \mu \mathrm{m}$ is not very well known. We find that using scanning electron micrographs of impregnated and polished sections of gouge, reliable GSD in the size range larger than $60 \mathrm{~nm}$ can be obtained.

In a previous study (Heilbronner \& Keulen, 2006) two types of gouge can be distinguished: cracked grains and gouge. Cracked grains and gouge can be discriminated on the basis of particle shape and grain size distributions. The D-values of gouge are always higher than those of cracked grains. Composition (quartz versus feldspar) influences various aspects of the particle shape of cracked grains and gouge (elongation, paris factor, etc.).

Table 1 shows a compilation of published results on the GSD of fault rocks: values of the fractal dimension vary between 0.8 and 2.6, but values of $\mathrm{D}$ between 1.5 and 2.1 are the most common for granitoid rocks. High D-values are generally obtained for more recently active fault zones, though a wide spread of D-values within a single fault zone can be observed.

As there appears to be a link between fault rock microstructure (shape and GSD) and the mechanical behavior of faults, and since fossil fault rocks are important clues to seismic activity in the past, this study focuses on the microstructures of naturally and experimentally produced faults. In this paper we examine the influence of experimental conditions on the fault rock microstructure and we compare the results to a natural fault rock cored from a recently active segment of the Nojima Fault (Japan). The focus of the paper is on the grain size distributions (D-values cracked grains and gouge) and on the geometry and spatial distribution of the fault rock in the samples (D-mapping). The aim is to study the influence of temperature, confining pressure, axial shortening rate, total axial shorten ing, and fluid content on the grain size development of gouge material in deformed granitoids. 


\section{Materials and methods}

\subsection{Description of sa mples}

\subsubsection{Verzasca gneiss:}

The starting material for the study of experimental fault rocks is cored from a gneiss that was collected in the Val Verzasca (location: Swiss coord inates 704.65 - 126.30, Figure 1a). The composition is granitic, consisting of $\sim 29 \%$ plagioclase, $\sim 27 \% \mathrm{~K}$-feldspar, $\sim 35 \%$ quartz and $\sim 7 \%$ mica, mainly biotite. The average grain size is $\sim 280 \mu \mathrm{m}$ and the rock exhibits a faint foliation and lineation while appearing isotropic at the thin section scale.

3.1.2 Nojima fault rock:

The samples for the study of natural fault rocks are taken from the Nojima fault, which transects a Cretaceous granodiorite and the overlying sediments of the Kobe Group and Osaka Group (Figure 1b). The modal composition of the granodiorite is $\sim 33 \%$ quartz, $\sim 34 \%$ plagioclase, $\sim 19 \% \mathrm{~K}$-feldspar, $\sim 11 \%$ biotite and $\sim 4 \%$ hornblende. One year after the Hyogoken Nambu Earthquake (Kobe Earthquake, 17 January 1995, Mw = 7.2) three bore holes have been drilled through the Nojima fault at different depths (Ito et al., 1999; Ohtani et al., 2000; Tanaka et al., 2001; Murakami et al., 2002). The fault rock samples studied here (Figure 1c and 1d) are from the Hirabayashi drill core, which has reached the fault zone at a depth between 623.1 to $625.3 \mathrm{~m}$ (the thin sections are provided by the Geological Survey of Japan).

The history, as derived from the cores, can be divided into two major deformation episodes (Boullier et al., 2004a). An earlier deformation episode is related to a left-lateral movement on the Nojima Fault (Fabbri et al., 2004) prior to the deposition of the Middle to Late Eocene Kobe Group. Pseudotachylytes associated with this episode have been dated at $56.4 \mathrm{Ma}$ by fission-tracks on zircons (Murak ami and Tagami, 2004). A more recent Quaternary deformation episode is associated with a right-lateral movement along the Nojima fault and offsets the Plio-Pleis tocene unconformity at the base of the Kobe Group (Murata et al., 2001). The studied thin sections are from the Quaternary deformation episode. 
Samples of Verzasca gneiss measuring $6.39 \mathrm{~mm}$ in diameter and 10.1 to $12.9 \mathrm{~mm}$ in length

$\left(\mathrm{L}_{0}\right)$ are cored parallel to the mesoscopic lineation. Table 2 lists the used abbreviations. At this size, the sample width corresponds to approximately 25 grains. After polishing their flat ends the samples are dried in an oven at $110^{\circ} \mathrm{C}$ and atmospheric pressure for at least 24 hours. The samples are wrapped in Ni-foil and placed in a gold jacket. In all cases except for experiment $63 \mathrm{nk}$, a "room-humidity" sample, approximately $0.2 \mathrm{wt} \% \mathrm{H}_{2} \mathrm{O}(1.68$ to $2.14 \mu \mathrm{l})$ is added and the jacket is weld-sealed. During welding, the jacket and sample are cooled in order to avoid water loss. The exact water content of the "wet" and "room-humidity" samples has not been determined, and we assume that also in room-humidity samples some water is present at grain boundaries.

Deformation is carried out in a Grigg's solid medium deformation apparatus as described by Tullis \& Tullis (1986) and De Ronde (2004), using straight furnaces, alumina pistons and sodium chloride as the confining medium. The pistons are slightly bevelled, thus reducing their diameter from $6.39 \mathrm{~mm}$ to $6.2 \mathrm{~mm}$ at the sample-p is ton interface. Temperature is measured with $\mathrm{Pt} / \mathrm{Pt}-10 \% \mathrm{Rh}$ or Crome1/Alumel thermocouples. The stand ard or reference deformation conditions are "wet" samples, $300^{\circ} \mathrm{C}$ temperature, $500 \mathrm{MPa}$ confining pressure, $10^{-4} \mathrm{~s}^{-1}$ shortening rate, and a total axial displacement of $3.5-5.0 \mathrm{~mm}$ (samples $38 \mathrm{nk}$ and 64nk). In separate runs, one or more parameters are varied: $500^{\circ} \mathrm{C}$ temperature, $1030 \mathrm{MPa}$ confining pressure, up to $5.8 \mathrm{~mm}$ to tal displacement, $10^{-6} \mathrm{~s}^{-1}$ shortening rate or no $\mathrm{H}_{2} \mathrm{O}$ is added (see Table 3). During the experiment, pressure, load and displacement are recorded on a strip chart. Using the rigC4 program (www.unibas.ch/earth/micro/software/), with a correction for rig stiffness, the force-displacement and stress-strain curves are calculated.

After the experiment, the samples are quenched. To avoid loss or damage of the non-cohesive fault rocks, the jackets are punctured and the samples are impregnated with epoxy. The samples are cut along the compressional axis and the deformed length of the sample is remeasured. Thin sections are prepared (polished and carbon coated) for observation in the light and scanning electron microscope. 
For the grain size analysis, images with a wide range of magnifications are used. The micrographs of the experimental microstructures are collected using a Philips XL30 ESEM scanning electron microscope ( $20 \mathrm{kV}$ acceleration voltage; backscatter contrast); those of the Nojima Fault Zone are acquired with a Leica Stereoscan 440 SEM. For each sample a cascade of micrographs is prepared, starting with overviews at low magnifications (100x) and zooming in (to 20,000x) on selected areas with a factor of 2 to 2.5 from one magnification to the next. At each magnification, three or four images are taken of each kind of fault rock (quartz, feld spar, cracked grains and gouge). The total range of grain sizes (radius, r) observable at these magnifications is from $<20 \mathrm{~nm}$ to $>200 \mu \mathrm{m}$, however, because of the scarcity of measurable grains at either end of the distribution, the statistically reliable range does not exceed three orders of magnitude.

We use Image SXM (http://reg.ssci.liv.ac.uk/) and ImageJ (http://rsb.info.nih.gov/ij/) and special Macros and Plug-Ins (http://www.unibas.ch/earth/micro/software) for segmentation and image analysis. First, the images are pre-processed (removal of noise) and scaled to pixels (Figure 2a). Bitmaps of quartz and feldspar grains are obtained by density slicing at the corresponding grey levels and subsequent separation of grains (Figure 2b). The cross sectional areas, $\mathrm{A}\left(\mathrm{pixel}^{2}\right.$ ), and the perimeters, $\mathrm{P}$ (pixel), of the grains are measured using the Analyze menu of the software. After removing grains with areas smaller than $20 \mathrm{pixel}^{2}, 300$ to 1200 grains per image could be used. Some of the images taken at the highest magnification could notbe processed automatically; in this case the grain boundaries are traced manually.

252

The resulting files of areas and perimeters were transferred to a spreadsheet program. The areas were restored by adding the pixel values of $\mathrm{P}$, i.e., the band of pixels outlining the grain, to the area $\mathrm{A}$ within the outline. The equivalent radii, $\mathrm{r}$, were calculated as and collected in a histogram (Figure 2c). On a $\log$ (frequency)- $\log ($ size) plot with $20 \mathrm{bins}$ per order of magnitude of grain size, the slope (D) of the power-law fit is determined (Figure 2d).

261 The results from all magnifications are then combined into a single plot (Figure 2e), 
images and corrects for areas in the micrograph that were not investigated (e.g. large grains at ed ge of the micrograph, cracks). Overlapping bins of grain radii have been analyzed to check the correct up-scaling; the average frequency of the overlapping bins is used to draw the comb ined GSD plot. Figure $2 \mathrm{f}$ shows the individual D-values as a function of magnification.

In all samples, two distinct $D$-values are obtained: a shallower slope $\left(D_{<}\right)$at smaller grain sizes and a steeper slope $\left(D_{>}\right)$at larger grain sizes. The change from $D_{<}$to $D_{>}$occurs at $r_{K}$. The point $r_{K}$ is determined in the following manner: On grain size plots derived from the magnification s around $r_{K}$, the curves for $D_{<}$and $D_{>}$are drawn. The intersection of the corresponding line yields $r_{K}$.

From the experimentally deformed Verzasca Gneiss, only limited fault rock material is available. We therefore use only one combined log-log plot and one (average) $\mathrm{D}_{>}$and $\mathrm{D}_{<}$ value per magnification. In the case of the Nojima fault zone, we have more fault rock samples. We have been able to evaluate a number of cascades from different samples of the drill cores and derive 4 to $5 \mathrm{D}_{<}$and $\mathrm{D}_{>}$values per magn ification.

For the evaluation of the largest grain sizes, light micrographs (taken with a ZEISS Axioplan Polarisation microscope) are included. The difference between the slopes $\left(D_{>}\right)$determined from light and scanning electron micrographs is less than 0.05 . We have also tested the reliability of the semi-automatic segmentation by comparing the derived D-values to D-values obtained from manual tracings of the outlines. On two sets of test images taken at magnifications of 500x and 2000x, the difference in $\mathrm{D}_{>}$is less than 0.04 .

\section{Results}

\subsection{Mechanical data}

The results of the triaxial compression experiments are shown as force-displacement diagrams (Figure 3a). With the exception of sample 60nk all samples display the same general behavior. Yield strength is reached after approximately $1 \mathrm{~mm}$ displacement, after that the load increases steadily, the differential stress decreases slowly after an axial shortening of $8-10 \%$. In some of the experiments deformed at $300^{\circ} \mathrm{C}$, reaching the yield strength was accompanied 
by audible cracking. Sample 60nk (run at the highest confining pressure) is different from all others in that it has produced distinct acoustic events, which accompany load drops on the order of $20 \mathrm{kN}$ (correspond ing to approximately $500 \mathrm{MPa}$ ).

300

At 45kN (1000-1200 MPa), sample 70nk, deformed at relatively high temperature $\left(500^{\circ} \mathrm{C}\right)$ and low axial shortening rate $\left(10^{-6} \mathrm{~s}^{-1}\right)$, is the weakest. At $60-75 \mathrm{kN}(1750 \mathrm{MPa})$ sample $63 \mathrm{nk}$ (room humidity sample) is the strongest. Samples deformed at standard conditions (64nk and $38 \mathrm{nk}$ ) support loads of 55-65 kN, corresponding to strengths of $1300-1500 \mathrm{MPa}$.

For comparison with published data, we also show a stress-strain diagram (Figure 3b). The differential stress is calculated with a correction for an increase in cross-sectional area, assuming constant volume. The Verzasca Gneiss has approximately the same strength as Westerly Granite (Fig. 3b) deformed by Tullis and Yund (1977). The main differences with respect to Westerly Granite experiments are the higher shortening at yield stress (with typical values $\sim 10 \%$ versus $\sim 5 \%$ ), the higher shortening rate (mainly at $10^{-4} \mathrm{~s}^{-1}$, see Table 3 ), and the amount of added water with which the Verzasca Gneiss has been deformed. In both sets of experiments, a temperature increase from $300^{\circ} \mathrm{C}$ to $500^{\circ} \mathrm{C}$ has caused a strength reduction of approximately $200 \mathrm{MPa}$. Note that Tullis and Yund (1977) have used pyrophyllite or talc as confining medium, which means that the true confining pressures probably are $\sim 2 / 3$ of the published values (J.Tullis, pers.comm., 2004).

We have noted a difference between the measured lengths of the deformed samples and the deformed lengths calculated from the total axial displacements derived from the forcedisplacement records (compare Figure $3 \mathrm{a}$ and Table 3). The calculated displacements exceed the measured displacements by up to $1 \mathrm{~mm}$. In the rest of the paper, we will therefore use the more conservative values of the measured displacements, not the displacements shown in Figure 3. This difference in measured length is not critical for the results, as the displacement is used semi-quantitatively in this study.

\subsection{Faulted sa mples}

In most samples deformed at $\mathrm{T}=300^{\circ} \mathrm{C}$ and $\mathrm{P}_{\mathrm{c}}=500 \mathrm{MPa}$, through-going fault zones are 
developed and partitioned the axial displacement over at least two fault zones, leading to a smaller displacement on any given fault. Sample 60nk deformed at $\mathrm{P}_{\mathrm{c}}=1030 \mathrm{MPa}$ shows a set of parallel faults. The corresponding load-displacement curve (Figure 3) shows an equivalent number of load drops. It is likely that each drop in the differential stress is related to the creation of a new fault plane.

The samples are deformed along relatively wide fault zones of 1.0-1.4 mm width, which become narrower with higher confining pressure or higher temperature; with increasing displacement, they tend to broaden. Most of the gouge zones are formed around mica grains or the connection of two mica grains. At a temperature of $300^{\circ} \mathrm{C}$ and shortening rates of $10^{-4}$ $\mathrm{s}^{-1}$ biotite deforms by gliding, kinking and occasionally by fracturing.

Using the D-mapping technique described elsewhere (Heilbronner \& Keulen, 2006), maps of local variations of the grain size distribution are prepared for three of the experimental samples (Figure 4). Cracking and gouge formation occur throughout the samples. In samples $38 \mathrm{nk}$ and $102 \mathrm{nk}$ gouge regions coalesce; in sample $60 \mathrm{nk}$ there is less coalescence. The volume proportion of gouge formed during the deformation is determined by measuring the black area (indicating $\mathrm{D}>1.75$ ) in Figure 4 and dividing this proportion by the total sample area. For increasing axial displacement, $d$, increasing amounts of gouge are formed. After $d=$ $4 \mathrm{~mm}$, sample $38 \mathrm{nk}$ (reference sample) has $24.5 \%$ of gouge; after $\mathrm{d}=5.8 \mathrm{~mm}$, sample $102 \mathrm{nk}$ (deformed at the same conditions) has $54.8 \%$. At higher confining pressures, there is less gouge: after $\mathrm{d}=3.5 \mathrm{~mm}$, sample $60 \mathrm{nk}\left(\mathrm{P}_{\mathrm{c}}=1000 \mathrm{MPa}\right)$ has only $15.5 \%$ gouge.

353

354

355

356

357

In the experiments at $\mathrm{P}_{\mathrm{c}}=500 \mathrm{MPa}$ and $\mathrm{T}=300^{\circ} \mathrm{C}$, the original grains in the gouge zone form broad and elongated arrays of fractured particles (Figure 5a); at higher confining pressures, these arrays are much narrower (Figure 5b). Quartz and feldspar are both strongly fractured; at higher confining pressures, quartz is less intensively fractured than feldspar. A variation in grain shapes can be observed: quartz grains are more elongated, feldspar grains are more irregularly shaped (Figure $5 \mathrm{c} \& 5 \mathrm{~d}$ ); the same variation in shape has been observed for a 364

sample deformed at low PT-conditions (Heilbronner and Keulen, 2006). 
365 Within the gouge zones, quartz and feldspar are fractured to very small grain sizes in all

366 experiments (Figure 5e \& 5f). The gouge is equidimensional and subangular in shape. In the

367 cracked grains and the gouge, the grains smaller than $2 \mu \mathrm{m}$ diameter do not show any

368 intragranular fractures, while grains larger than $10 \mu \mathrm{m}$ are usually fractured into a spectrum of

369 smaller grains (Figure $5 \mathrm{~g} \& 5 \mathrm{~h}$ ). Also, grains smaller than $1 \mu \mathrm{m}$ are equiaxial and appear

370 weakly indented. Within the gouge these small grains show more rounded edges.

371

372

373

374

375

376

377

The grain size distributions of all of our experiments display the same general characteristics

378 (Figure 6). On log-log plots of frequency versus equivalent radius, two distinct parts can be discriminated (compare also Heilbronner \& Keulen, 2006). Both for cracked grains and gouge, two D-values are obtained: a lower value, $\mathrm{D}_{<}$, for small grain sizes and a higher value, $\mathrm{D}_{>}$, for larger grain sizes. The grain size, $\mathrm{r}_{\mathrm{K}}$, at the intersection of the two curve fits is on the order of $1-2 \mu \mathrm{m}$. In gouge, the lower range of grain sizes extends from $\mathrm{r}_{\min } \approx 20 \mathrm{~nm}$ to $\mathrm{r}_{\mathrm{K}} \approx 2$ $\mu \mathrm{m}$ with $\mathrm{D}_{<} \approx 1.0$ and the upper range extends from $\mathrm{r}_{\mathrm{K}}$ to $\mathrm{r}_{\max } \approx 20 \mu \mathrm{m}$ with $\mathrm{D}_{>} \approx 2.0$. In cracked grains, the lower range of grain sizes extends from $\mathrm{r}_{\min } \approx 50 \mathrm{~nm}$ to $\mathrm{r}_{\mathrm{K}} \approx 1.5 \mu \mathrm{m}$ with $\mathrm{D}_{<} \approx 1.0$ and the upper range extends from $\mathrm{r}_{\mathrm{K}}$ to $\mathrm{r}_{\max } \approx 100 \mu \mathrm{m}$ with $\mathrm{D}>\approx 1.5$.

Comparing feldspar and quartz we note that the $\mathrm{D}_{<}$values are approximately identical under almost all experimental conditions ranging from 0.72 to 1.02 in cracked feldspar, 0.74 to 1.09 in cracked quartz, from 0.91 to 1.12 in feldspar gouge and 0.78 to 1.10 in quartz gouge (Table 4). The $\mathrm{D}>$ values, in contrast, are usually higher for quartz than for feldspar ranging from 1.37 to 1.68 in cracked feld spar, 1.44 to 1.72 in cracked quartz, from 1.85 to 2.12 in feldspar gouge and 1.94 to 2.32 in quartz gouge (Table 4).

On average, the grain size, $\mathrm{r}_{\mathrm{K}}$, of cracked grains is slightly larger than in gouge (Table 5). However, this effect is more pronounced in quartz than in feldspar. The grain size, $r_{K}$, of cracked quartz ranges from $1.1-1.8 \mu \mathrm{m}$ and is smaller than $r_{K}$ of cracked feldspar which ranges from 1.6-2.0 $\mu \mathrm{m}$. Similarly, in gouge, $r_{K}$ of quartz is $1.1-1.4 \mu \mathrm{m}$ while $r_{K}$ of feldspar is $1.4-2.0 \mu \mathrm{m}$. 
The GSD of the experimentally deformed granitoid samples are shown in Figure $6 \& 7$, the derived values of $D_{<}, D_{>}$, and $r_{K}$ are shown in Tables $4 \& 5$. The $d_{K}$ grain diameter is two times the $\mathrm{r}_{\mathrm{K}}$ grain radius indicated in Figure 6, and has been used to compare our data to other studies. We consider the samples $64 \mathrm{nk}$ and $38 \mathrm{nk}$ as reference samples. The experiments are performed at $\mathrm{T}=300^{\circ} \mathrm{C}$, confining pressure $\mathrm{P}_{\mathrm{c}}=500 \mathrm{MPa}$, shortening rate $\cdot \varepsilon=1.5 \cdot 10^{-4} \mathrm{~s}^{-1}$ and $0.2 \%$ wt $\mathrm{H}_{2} \mathrm{O}$ was added to the samples. The total axial displacement, $\Delta \mathrm{L}$, of $64 \mathrm{nk}$ and $38 \mathrm{nk}$ is 2.2 and $3 \mathrm{~mm}$, respectively. In Figure 6, each of the plots shows the GSDs resulting from the change of one of the experimental conditions with respect to $64 \mathrm{nk}$.

The reference values derived from the GSDs of sample 64nk and 38nk are the following: $\mathrm{D}_{<}$ ranges from 0.95 to $1.07\left(\mathrm{D}_{<}\right.$of cracked feldspar $=1.00 ; \mathrm{D}_{<}$of feldspar gouge $=1.02 ; \mathrm{D}_{<}$of cracked quartz $=0.95 ; \mathrm{D}_{<}$of quartz gouge $\left.=1.07\right)$, cracked grains have somewhat lower values than gouge. $\mathrm{r}_{\mathrm{K}}$ is $1.1-1.8 \mu \mathrm{m}$ ( cracked feldspar $=1.8 \mu \mathrm{m} ; \mathrm{r}_{\mathrm{K}}$ of feldspar gouge $=1.6$ $\mu \mathrm{m} ; \mathrm{r}_{\mathrm{K}}$ of cracked quartz $=1.6 \mu \mathrm{m} ; \mathrm{r}_{\mathrm{K}}$ of quartz gouge $\left.=1.1 \mu \mathrm{m}\right)$, quartz yields lower values than feldspar and cracked grains have higher values than gouge. $D_{>}$is $1.5-1.6$ for cracked grains $(\mathrm{D}>$ of cracked feldspar $=1.6 ; \mathrm{D}>$ of cracked quartz $=1.5)$ and $2.04-2.26$ for gouge ( $\mathrm{D}_{>}$of feldspar gouge $=2.04 ; \mathrm{D}_{>}$of quart gouge $=2.26$ ), quartz has a lower $\mathrm{D}_{>}$-value than feld spar for cracked grain s and a higher $\mathrm{D}_{>}$-value for gouge.

Increasing the confining pressure from $500 \mathrm{MPa}$ to $1030 \mathrm{MPa}$ leads to a marked reduction of both $\mathrm{D}_{<}$and $\mathrm{D}_{>}$, both for cracked grains and gouge. The grain sizes, $\mathrm{r}_{\mathrm{K}}$, at the slope break of cracked grains and gouge do not change significantly, with the possible exceptions of $r_{K}$ of feld spar gouge and cracked quartz: these values increase from 1.6 to $1.8 \mu \mathrm{m}$ and from 1.5 to $1.8 \mu \mathrm{m}$, respectively. This variation is within the error of the measurements.

Reducing the shortening rate from $10^{-4} \mathrm{~s}^{-1}$ to $10^{-6} \mathrm{~s}^{-1}$ does not affect the values of $\mathrm{D}_{>}$; of the $\mathrm{D}_{<}$ values only th ose of cracked feldspar and of quartz gouge appear to be lowered: from 1.00 to 0.86 and 1.07 to 0.97 , respectively. The grain size $r_{K}$ of feldspar remains unchanged, while respectively. 
432 Increasing the axial shortening from $2.2 \mathrm{~mm}$ to $4.8 \mathrm{~mm}$ has no significant effect on any of the

433 measured values. As has been mentioned before, the only difference between samples 64nk

$434(\Delta \mathrm{L}=2.2 \mathrm{~mm}), 38 \mathrm{nk}(\Delta \mathrm{L}=3.0 \mathrm{~mm})$ and $102 \mathrm{nk}(\Delta \mathrm{L}=4.8 \mathrm{~mm})$ is the wid th of the fault

435 zone(s), i.e., the amount of fault rock (cracked grains and gouge) created during deformation.

436

Deforming the sample without adding water (under room-humidity conditions) has a marked effect on the GSD. With the exception of feldspar gouge, all $\mathrm{D}_{<}$values are lowered significantly to values as low as 0.72 to 0.83 . At the same time, all values of $\mathrm{D}$ > increase. The grain size at the slope break is not affected except for $\mathrm{r}_{\mathrm{K}}$ of cracked quartz, which is lowered 441 from 1.5 to $1.2 \mu \mathrm{m}$.

Increasing the temperature from $300^{\circ} \mathrm{C}$ to $500^{\circ} \mathrm{C}$ affects the $\mathrm{D}>$ values. In particular, the values for feldspar gouge and quartz gouge are lowered from 2.04 to 1.95 and from 2.26 to 2.07 , respectively. The major effect on $r_{K}$ is to increase the values for feldspar and quart gouge from 1.6 to $2.0 \mu \mathrm{m}$ and from 1.1 to $1.4 \mu \mathrm{m}$, respectively.

\subsection{Grain size analysis of natural fault rocks}

For the Nojima samples the GSDs are given as bulk results, i.e., the different mineral phases, in particular, quartz and feldspar, were not separated. Comparing the GSDs of cracked minerals and gouge to the experimental results, we note that the values of $\mathrm{D}_{<}(1.64$ and 2.02), $\mathrm{D}_{>}(0.97)$ and $\mathrm{r}_{\mathrm{K}}(1.9 \mu \mathrm{m}$ and $1.5 \mu \mathrm{m})$ are very close to the corresponding values obtained for feld spar cracked grains and gouge (see Table 4, Figure 8).

\subsection{Characteristics of GSDs}

The GSDs of both the experimental and natural fault rocks display a number of characteristics that we want to highlight (compare Figure $6,7 \& 8$ ). The lower limit of grain sizes that could be used for the calculation of statistically reliable distributions is $r_{\min }=30$ to $60 \mathrm{~nm}$ for experimentally produced and $r_{\min }=100$ to $200 \mathrm{~nm}$ for naturally produced gouge and cracked grains, respectively. Similarly, the upper limit is $r_{\max }=50-100 \mu \mathrm{m}$ for experimentally produced and $r_{\max }=100-200 \mu \mathrm{m}$ for naturally produced gouge and cracked grain $\mathrm{s}$, 
respectively. In other words $r_{\min }$ and $r_{\max }$ of gouge are always smaller than $r_{\min }$ and $r_{\max }$ of cracked grains by a factor of $\sim 2$. Note, however, that $r_{\min }$ is not the absolutely smallest grain size that can be detected in the SEM (Figure 9). Grains as small as $\mathrm{r} \approx 5 \mathrm{~nm}$ have been detected both in experimental and in natural fault rocks, but are at the detection limit of the SEM so that their number is not large enough for a grain size analysis.

The grain size $r_{K}$ at the slope break of the power law fit to the GSD has a remarkably constant value. In contrast to the marked decrease of minimum and maximum grain size from cracked grains to gouge, the $\mathrm{r}_{\mathrm{K}}$ values remain approximately constant or decrease by $<30 \%$ from an average value of 1.7 to $1.4 \mu \mathrm{m}$ in experimental and from 1.9 to $1.5 \mu \mathrm{m}$ in natural fault rocks (Figure 10).

\section{Discussion}

\subsection{Faulting experiments}

481

Brittle deformation experiments on granitoid rock at elevated pressure-temperature conditions have been performed by Griggs et al. (1960); Stesky et al. (1974); Carter et al. (1981); Blanpied et al. (1995); Kato et al. (2003) and others. Our experiments on Verzasca Gneiss compare best with the data on Westerly Granite published by Griggs et al. (1960) and Tullis and Yund $(1977,1980)$. The geometry and distribution of strain in our samples is variable (Figure 4). Therefore, we prefer to present our mechanical data in terms of force versus axial displacement rather than stress and strain (Figure 3a). For comparison with published data, we have converted our force data to stress data (Figure $3 b$ ).

The experiments on Westerly Granite at $\mathrm{P}_{\mathrm{c}}=500$ and $750 \mathrm{MPa}$ have been preformed without added water; samples have been pre-dried at a higher temperature $\left(300^{\circ} \mathrm{C}\right)$ than ours (Tullis \& Yund 1977). Since pyrophyllite or talc has been used as outer confining medium, the confining pressure has been reduced to approximately 350 and $500 \mathrm{MPa}$. Their experiments at $750 \mathrm{MPa}$ are therefore best compared to ours at $500 \mathrm{MPa}$, because we use $\mathrm{NaCl}$ as outer confining medium. The strengths of Westerly Granite and Verzasca Gneiss are comparable showing strengths of 1200 to $1600 \mathrm{MPa}$ under similar conditions, although no experiments have been performed under identical conditions. The variation of the bulk shortening rate 
between $10^{-4}$ and $10^{-6} \mathrm{~s}^{-1}$ does not show any mechanical effect, consistent with the results of Tullis \& Yund $(1980,1992)$.

The effect of a high confining pressure ( 1 GPa) is comparable to experiments by Tullis \& Yund $(1977,1980)$. Very narrow slip zones accommodate the axial shortening. According to Tullis and Yund (1977) and Hirth and Tullis (1994), the formation of these narrow zones and the decrease in volume of fault rock is related to the transition from mode I to mode II cracking above $\mathrm{P}_{\mathrm{c}} \approx 600-800 \mathrm{MPa}$. The number of these narrow zones corresponds to the number of audible cracking events in the experiment 60nk. This observation suggests that the mechanical behavior is not a case of stick-slip as described in the literature (e.g. Byerlee and Brace, 1968; Stesky et al., 1974; Lockner et al., 1986). Instead, the apparent stick slip character of the mechanical data (Figure 3) is produced by multiple rupture events, demonstrating the great strength of already ruptured material at high confining pressure.

\subsection{Grain size distributions obtained in experiments}

Changing the physical parameters of experimental deformation also affects the grain size distribution. The effects are discussed with reference to sample 38nk and 64nk, which have been deformed under identical temperature, pressure and shortening rate conditions.

The largest effect is observed for increasing the confining pressure to $\sim 1 \mathrm{GPa}$. It causes a

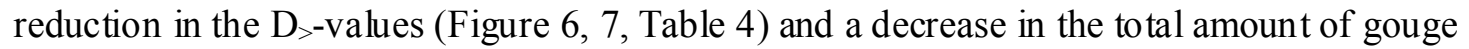
and cracked grains in the fault zone (see Figure 4). This smaller amount of gouge is related to the transition from mode I to mode II cracking: mode I fracturing is dilatant; in mode II fracturing sharp shear fractures are formed when dilatancy is suppressed. Dilatancy suppression appears to inhibit the formation of large amounts of surface (small grains) and thus may reduce the $\mathrm{D}_{\succ}$-value.

At higher temperatures, there is a decrease in the $\mathrm{D}_{>}$values of the gouge (Figure 7, Table 4). In feldspar deformed at $\mathrm{T}=500^{\circ} \mathrm{C}$ we observe undulatory extinction and deformation bands, which are developed by micro-cracking at a very small scale, as described by Tullis and Yund (1987). At a temperature of $500^{\circ} \mathrm{C}$, Hirth \& Tullis (1994) have found an increased dislocation 
activity in quartz. The less efficient grain size reduction at elevated temperature may be caused by a semi-brittle behavior.

The effects of not adding water and slower shortening rate are either unsystematic (higher $\mathrm{D}_{<}$values for feldspar and lower $\mathrm{D}_{<}$values for quartz in gouge of non-water added sample 63nk; Table 4) or not existent (samples 38nk, 64nk, 102nk; Table 4). The D-values are the same regardless of the amount of shortening of the sample (Figure 7, Table 3).

After $4 \mathrm{~mm}$ axial shortening a gouge of $1.0 \mathrm{~mm}$ thickness has been formed. Once a mature zone with gouge is established, this zone is growing wider at greater displacement, but $\mathrm{D}>$ of the gouge is not changing. Marone and Scholz (1989) have also observed similar D-values for different shear strains. In general, it can be concluded that the effects of changing the physical conditions of deformation on the grain size distribution are of minor importance except for the increase in confining pressure, and, to a lesser extent, temperature.

\subsection{Cracked material and gouge}

All experimental and Nojima fault rock samples show the same type of grain size distribution (GSD). For small grain sizes $(\mathrm{d}<2-3 \mu \mathrm{m})$ the GSD is characterized by D-values of $\sim 1$, whereas for the larger sizes the D-values range between $\sim 1.5$ and $\sim 2.3$ (Table 4). The gouge always shows higher D-values than the cracked material (Figure 6, 8, Table 4). It is interesting to note that the values of $\mathrm{D}_{<}$in cracked material and gouge, in quartz and feldspar, and in experimental and in Nojima fault rocks all have very similar values and the same range of variation (Table 4). Furthermore, this grain size range is not affected by changing the experimental deformation conditions. In contrast, $\mathrm{D}>$ of gouge is the parameter that has been measured in several other studies before (Table 1). It is the most suitable of the D-values to compare natural fault zones in different regions or to compare natural faults with experimentally obtained values.

Higher D-values indicate a more efficient grain size comminution producing a larger number of smaller grains. The difference between gouge and cracked grains clearly demonstrates that the initial rupturing process does not produce the full amount and size fraction of small grains observed in gouge (Figure 6,8). Instead, slip on the fault zone causes further comminution of grains in the gouge and an increase in $\mathrm{D}_{>}$. Thus, it can be concluded that after the initial 
fragmentation of the rock by rupturing there is a post-rupture processing during slip which takes place in the gouge to produce the higher values of $\mathrm{D}_{>}$.

Further comminution of grains in gouge has been observed by Sammis et al. $(1986,1987)$ and Hadizadeh \& Johnson (2003). However, any quantitative characterization of fault displacement by GSD measurements appears impossible because an increase in sample shortening from 2.2 to $4.8 \mathrm{~mm}$ in our experiments (64nk and 102nk) does not change any of the D-values systematically (Figure 6, 9, Table 5). Thus, the more efficient grain comminution in gouge must take place in the first stages of the fault displacement after rupturing.

In the experiments performed under identical conditions $(38 \mathrm{nk}, 64 \mathrm{nk}, 102 \mathrm{nk})$ the variation of D-values of the cracked material is always larger than in the gouge (Table 4). The only systematic difference appears to be the consistently higher $D_{>}$values of quartz gouge compared to feldspar gouge, i.e., for the coarser grain size fraction $(>2 \mu \mathrm{m})$ quartz shows a more efficient comminution of grains than feldspar. The $\mathrm{D}_{>}$-values for quart $\mathrm{and}$ feldspar gouge are almost identical in these three experiments and indicate that this D-value is very well reproducible and therefore forms a reliable parameter to compare the GSD of fault zones. Another difference is the lower $r_{\mathrm{K}}$-value for quartz compared to feldspar. Thus, the change in the GSD occurs at $\sim 1 \mu \mathrm{m}$ in quartz, while it occurs at $\sim 2 \mu \mathrm{m}$ in feldspar (Table 4 ).

\subsection{Natural fault rock}

The range of values in the natural samples from the Nojima fault is approximately the same as those of the feldspars in experiments (Figure 6, 8, Table 4) so that the natural fault rock appears to behave in a similar way as feldspar. The granodiorite deformed by the Nojima fault consists of $\sim 53 \%$ feldspar (plagioclase and K-feldspar); therefore, feldspar is expected to play a dominant role in the GSD of a mixed gouge.

\section{The recently formed fault rock of the Nojima Fault zone shows the same D-values as the} experimentally deformed granitoid rock, especially for feldspar minerals. If we compare the D-values of the recent deformation episode with feldspar in experiment $64 \mathrm{nk}$ and $38 \mathrm{nk}$, performed at $\mathrm{T}=300^{\circ} \mathrm{C}, \mathrm{P}_{\mathrm{c}}=500 \mathrm{MPa}, \cdot \varepsilon=1.5 \cdot 10^{-4} \mathrm{~s}^{-1}$, with $<4 \mathrm{~mm}$ shortening and with 0.2 
602

603

604

605

606

607

608

609

610

611

612

613

614

615

616

617

618

619

620

621

622

623

624

625

626

627

628

629

630

631

632

$\mathrm{wt} \% \mathrm{H}_{2} \mathrm{O}$ added to the sample, all D-values are the same within the error of 0.05 .

Temperature and pressure conditions during Nojima deformation were lower than in the deformation experiments.

$\mathrm{D}_{>}$of the Nojima gouge $\left(\mathrm{D}_{>}=2.02\right)$ is in fairly good agreement with data from coarser grain size fractions by Monzawa and Otsuki (2003); they obtain $\mathrm{D}_{>}=2.192$ to 2.559, for five different samples of the surface outcrop of the Nojima Fault Zone, with a mean of 2.347. Monzawa and Otsuki's (2003) data is more similar to the values of $D_{>}$for the experimentally deformed quartz so that all data appears to be within the variation of the experimental data.

Our results are consistent with studies of other fault zones (Table 1). Blenkinsop (1991) and An and Sammis (1994) describe both low $\left(D_{>}<1.6\right)$ and high $\left(D_{>}>2.0\right)$ values for analyses of gouge originating from the same fault zone. Several other studies describe high $\mathrm{D}_{>} \mathrm{v}$ alues (e.g. Blenkinsop, 1991; Hadizadeh and Johnson, 2003). In some gouge the lower limit of D> is 1.4 to 1.6, except for the San Andreas Fault Cajon Pass Drillhole granite $(\mathrm{D}=0.8$;

Blenkinsop, 1991). We speculate that these gouge with $\mathrm{D}_{>}$below 1.6 might be monomineralic gouge where fluids and temperature caused healing (e.g. Sammis et al., 1987, Keulen et al., submitted) or were only cracked (e.g. Marone and Scholz, 1989).

\subsection{Surface densit ies of fault rocks}

The surface energy in gouge can be used to calculate a part of the energy release during an earthquake event (Kanamori, 1994; Wilson et al., 2005; Chester et al., 2005; Ma et al., 2006).

The grain size distribution allows the calculation of the total surface area of the fault rock (Chester et al. 2005, Wilson et al. 2005). The estimates of Chester et al. (2005) for the Punchbowl fault are based on GSDs with an assumed minimum grain size, $r_{\min }$, of $1.6 \mathrm{~nm}$ and a constant D-value of 3 (= 2 in 2 dimensions) for the en tire grain size range. In contrast, we find that in all of our experimental and natural samples the D-value below $r \approx 1$ to $2 \mu \mathrm{m}$ is $\mathrm{D}_{<}$ $\approx 1$.

If the evolution of the GSD is a two-stage process involving initial rupturing and further grain comminution in the gouge, probably by attrition, shearing, grinding, etc.; it is questionable whether the surface energy calculated from the GSD can directly be related to the seismic energy release as proposed by Wilson et al. (2005) and Chester et al. (2005). Neither is the 
633

634

635

636

637

638

639

640

641

642

643

644

645

646

647

648

649

650

651

652

653

654

655

656

657

658

659

660

661

662

663

664

665

666

surface energy obtained from the GSD of fault rocks identical to the specific surface en ergy as applied in earthquake energy budget calculations (e.g. Ventakaraman \& Kanamori, 2004). For the following calculation we use the surface density of cracked grains, but not of gouge, to compare to the data of Wilson et al. (2005) and Chester et al. (2005), because we assume that this is the material, which is created by the rupture process during the seismic event, while the higher surface density of gouge is due to the combined effect of fracturing and subsequent deformation during slip.

To estimate the surface density for our cracked minerals and gouge we use the concept of the fractal fragmentation of the cube and a simple spread sheet program. We set up a histogram of 13 (logarithmic) bins, extend ing from $0.03 \mu \mathrm{m}$ to $128 \mu \mathrm{m}$ and from $0.015 \mu \mathrm{m}$ to $64 \mu \mathrm{m}$, respectively. Between $r_{\min }$ and $r_{K}$, the 3-dimensional fractal dimension is set to 2 in both cases, corresponding to a value of $D_{<}=1.0$. Between $r_{K}$ and $r_{\max }$, the fractal dimension is set to 2.5 for cracked material and to 3 for gouge, corresponding to $\mathrm{D}_{>}=1.50$ and $\mathrm{D}_{>}=2.00$, respectively. A value of $r_{K}=1 \mu \mathrm{m}$ is assumed in both cases. For each of the bins, the number, total volume and total surface of the cubes is calculated. Summing over all bins, the surface to volume ratio of cracked material and gouge is 1.3 and $6.0 \mu \mathrm{m}^{2} / \mu \mathrm{m}^{3}$ i.e., $1.3 \cdot 10^{6} \mathrm{~m}^{-1}$ and $6.0 \cdot 10^{6} \mathrm{~m}^{-1}$ for cracked material and gouge.

Using the same approach to calculate surface densities for the Punchbowl Fault using the data $\left(r_{\min }=1.6 \mathrm{~nm}\right.$ and $\left.\mathrm{r}_{\max }=100 \mu \mathrm{m}, \mathrm{D}=2.0\right)$ given by Chester et al. $(2005)$, we obtain $6.8 \cdot 10^{8}$ $\mathrm{m}^{-1}$. If we now compare our value of cracked grains of $1.3 \cdot 10^{6} \mathrm{~m}^{-1}$ to a value of $4.2 \cdot 10^{8} \mathrm{~m}^{-1}$ (corresponding to $4.2 \cdot 10^{5} \mathrm{~m}^{2}$ in the $1 \mathrm{~mm}$ thick layer of the fault, given by Chester et al., 2005 ) or $2.7 \cdot 10^{8} \mathrm{~m}^{-1}$ (corresponding to $80 \mathrm{~m}^{2} \mathrm{~g}^{-1}$ given by Wilson et al., 2005) we no te that in our case, the surface density, and accordin gly, the energy required to generate it, is smaller than the values assumed by Wilson et al. (2005) and Chester et al. (2005) by a factor of 200 to 300. Finding that the surface densities in cracked rocks and even in gouge are so low suggests to us that the creation of those surfaces cannot play a major role in the energy budget of a seismic event.

The discrepancy between our data and the data published by Chester et al. (2005) can be explained by the fact that they have measured their small grain size fraction (down to $r=25$ $\mathrm{nm}$ ) in the TEM, which is a notoriously difficult method for obtaining good statistics of any parameter observed. Thus, they did not detect the change of D-values at $r \approx 1 \mu \mathrm{m}$. Using $\mathrm{D}=$ 
2.0 over the entire range of grain sizes results in a total surface area which is 2 orders of magnitude too high. Furthermore, they assume $r_{\min }=1.6 \mathrm{~nm}$ and thus many tiny grains with a high surface area density. Note that finding lower surface densities rather supports and strengthens their general conclusion that the surface energies do not contribute in any major way to the energy dissipated during earthquakes. Pittarello et al. (2006) come to the same conclusion, using GSD measurements of pseudotachylyte-related granitoid cataclasites.

\subsection{Grinding limit}

Grains with very small radii formed by comminution have been found before in deformation experiments ( $d=10 \mathrm{~nm}$; Yund et al., 1990), in mining induced fault zones ( $\sim 40 \mathrm{~nm}$; Olgaard and Brace, 1983; Wilson et al., 2005) and in natural fault zones (40 nm; Wilson et al., 2005, Chester et al. 2005). We observe grains of $30 \mathrm{~nm}$ in both experimental and natural fault rock (Figure 9) $\mathrm{r}_{\mathrm{K}}$ is $1.2 \pm 0.3 \mu \mathrm{m}$ for quartz and $1.8 \pm 0.3 \mu \mathrm{m}$ for feldspar grains. The slope change is observed for both cracked grains and gouge (Figure 6, 8, Table 5). Very small grains are already formed upon cracking of the grains; they are not only a product of gouge formation. $\mathrm{D}_{<}$is less dependent on deformation conditions, the type of mineral (quartz or feld spar) and is more similar for cracked grains and gouge than $D_{>}$.

Kendall (1978) has demonstrated that a critical radius exists below which particles cannot be comminuted further by grinding. This critical radius, called the grinding limit, is $0.3 \mu \mathrm{m}$ for $\mathrm{SiO}_{2}$ glass, $0.9 \mu \mathrm{m}$ for quartz and $2.2 \mu \mathrm{m}$ for calcite (Steier and Schönert, 1972 in Prasher, 1987). Small particles have a different internal stress distribution and are stronger due to smaller flaw sizes and flaw size density (Prasher, 1987) so that very high stresses are required to break them (Mitra, 1978). This is consistent with our observation that no intragranular cracks within grains smaller than $1 \mu \mathrm{m}$ in radius are observed.

The $\mathrm{r}_{\mathrm{K}}$-values for quart $\mathrm{are}$ slightly higher than the grinding limit (given as radius) for quartz (Figure 10). There is no data for the feldspar grinding limit available but the higher $\mathrm{r}_{\mathrm{K}}$-values for feldspar (Figure 10) are cons istent with the observation that the critical grain size for grinding is linearly dependent on the elastic modulus E of the mineral (Kendall, 1978), because the bulk E-modulus of feldspar is approximately 2 times that of quartz (Bass, 1995). 
700 Thus, it appears likely that $r_{\mathrm{K}}$ represents approximately the grinding limit in the comminution

701 of fault rock. For smaller grain sizes, where grinding is inhibited, communition is less

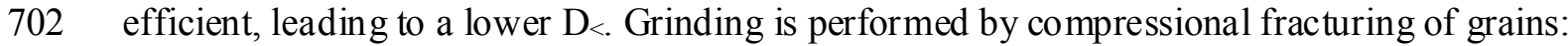

703 a network of cracks will develop and the grain will break into several smaller ones (Jaeger,

704 1967). Other processes, like shearing or attrition also produce comminution. Reches and

705 Dewers (2005) and Dor et al. (2006) describe comminution as dynamic pulverization

706 (explosive granulation followed by dynamic contraction) at earthquake crack tips. For grains

707 smaller than $\mathrm{r}_{\mathrm{K}}$ compressional fracturing appears inhibited, but shearing or attrition remains

708 significant. From the difference between D-values in cracked grains and gouge, it is clear that

709 grinding, shearing and attrition during slip cause further comminution in gouge.

710

711

712

713

714

715

716

717

718

719

720

721

722

723

724

725

726

727

728

729

730

731

732

733

\subsection{Fractal dimension}

Fractal dimensions are used to describe geometries that are scale invariant (Turcotte, 1992).

To describe a GSD as fractal, this distribution should lie on a straight line over several orders of magnitude in a $\log ($ frequency)-log(size) distribution. The GSD of both the experiments and the Nojima Fault Zone gouge does not show a fractal distribution. The data cover 3.5 orders

of magnitude, but cannot be fitted with a single straight line. Furthermore, there are statistical problems because most fault rock grain size measurements only cover 1 to 4 orders of magnitude.

The advantage of having a fractal distribution is the scale invariance of the measurements.

Analyses performed on laboratory experiments or on hand specimens could easily be extrapolated to large fault systems. However, Turcotte (1992) emphasizes that not every power-law distribution can be described by a fractal dimension. Fractal dimensions are limited to D-values between 0 and 2 in 2D (Turcotte, 1992), so that gouge with $D_{>}$larger than 2.0 cannot be described as fractal.

Several authors have commented on the ideal nature of a fractal dimension or D-value of 1.6: a GSD with a D-value of 1.6 appears the most ideal for close packing (Monzawa and Otsuki, 2003). Hoffmann and Schönert (1971) and Sammis et al. (1987) describe a D-value of 1.6 (for constrained comminution) as ideal, because the probability that grains of the same size are neighboring each other and the amount of pore space for a close-packed array of spherical grains are minimized. Morgan (1999) and Morgan and Boettcher (1999) have shown with 
numerical simulations of gouge that a $\mathrm{D}$ of 1.6 marks the onset of shear localization, interparticle rolling, and a decrease in the general comminution rate. Biegel et al. (1989) and Marone and Scholz (1989) find a D-value of 1.6 for the onset of shear localization in their experimentally formed gouge. It seems that the onset of gouge evolution from cracked grains, leading to an increase of $\mathrm{D}_{>}$above 1.6, causes dilatancy (less close packing), which will increase the possibility for grinding, creating more small grains and thus a higher $\mathrm{D}_{\text {٪. }}$. Dilatancy may allow for inter-particle rolling; in this way smaller and rounder grains are formed, therefore $\mathrm{D}>$ is increased and more grains with $\mathrm{r} \leq \mathrm{r}_{\mathrm{K}}$ are formed. The smaller $\mathrm{D}$ values of gouge in high confining pressure experiments support such an interpretation, because of the effective suppression of dilatancy at high pressures.

Storti et al. (2003) report measurements in carbonate fault zones, in which the D-values at the boundary of the shear zone are between 0.9 and 1.4 and evolve to D-values between 1.6 and 2.5 for the interior shear bands. These observations are consistent with our observations: gouge ( $\mathrm{D}>1.6)$ is localized in slip zones, whereas cracked grains $(\mathrm{D}<1.6)$ make up a larger part of the sample without major slip.

\section{Conclusions}

753

The analyzed fault rocks derived from experimentally faulted granite and from the Nojima fault zone consist of two different types of material, cracked grains and gouge. These can be distinguished on the basis of their microstructures and their grain size distribution (GSD). On $\log -\log$ plots the GSDs display two distinct power-law fits: $\mathrm{D}_{<}$for grain sizes smaller than $\mathrm{r}_{\mathrm{K}}$ and $\mathrm{D}>$ for grain sizes larger than $\mathrm{r}_{\mathrm{K}}$. $\mathrm{D}>$ is the value that corresponds to other published $\mathrm{D}$ values (so-called "fractal dimensions").

$\mathrm{D}_{<}$is $0.9-1.0$ for cracked grains and 0.9-1.1 for gouge and more or less independent of the deformation conditions or the type of mineral. The lower limit of grain sizes in experimentally and naturally produced gouge is $r=15 \mathrm{~nm}$.

D> is 1.5-1.6 for cracked grains and 2.0-2.3 for gouge and depends on the deformation 
$767100 \mu \mathrm{m}$. $\mathrm{D}>$ for gouge is a good parameter to compare natural and experimental fault rock of 768 grain sizes smaller than $\sim 100 \mu \mathrm{m}$.

Cracked grains result from initial fragmentation by rupturing. They develop into gouge by subsequent grain comminution, grind ing, attrition, or shear during slip along the fault zone. These processes produce larger $\mathrm{D}_{>}$-values and therefore represent a more efficient grain size reduction for quartz and feldspar grains in the size range greater than 1-2 $\mu \mathrm{m}$.

774

The grain size, $r_{K}$, at the slope break of the $\log$ (frequency)- $\log ($ size $)$ histogram of the GSD occurs at $1.2 \pm 0.3 \mu \mathrm{m}$ for quartz and at $1.8 \pm 0.3 \mu \mathrm{m}$ for feldspar. The grain size $\mathrm{r}_{\mathrm{K}}$ coincides approximately with the grinding limit in quartz and probably corresponds to a change in the physical process of grain comminution. Attrition and shear may dominate below the transition value $r_{K}$.

Most of the experimental conditions during deformation (temperature, confining pressure, $\mathrm{H}_{2} \mathrm{O}$-con tent, displacement rate) have a minor effect on the GSD. Most noticeable is an increase in confining pressure ( $\sim \mathrm{GPa})$, which reduces the efficiency of grain comminution.

The gouge of the Nojima Fault Zone shows $\mathrm{D}_{>}=2.02$ for gouge and 1.64 for cracked grains. These values are the same as for the experimen tally deformed granitoids.

Experiments and natural seismic fault rocks from the Nojima fault zone show the same GSD, although the experiments have been carried out at higher PT-conditions and at considerably slower displacement rates than in nature.

The development of the GSD is a two-stage process. First rupturing of the rock causes cracked grains that evolve to a gouge as a result of further movement on the fault zone. The surface densities calculated from the GSD of cracked minerals and gouge are 200-300 times lower than published data, confirming that the creation of surface plays a minor role in the energy budget of earthquakes. 
802 The authors thank Jan Tullis and Chris Spiers for discussion and Jan for providing thin 803 sections of her Westerly Granite samples. We thank H.R. Rü egg and C. Schneider for 804 technical and A. de Ronde for scientific and general support in the laboratory. W. Tschudin 805 provided excellent thin sections. The Geological Survey of Japan is thanked for the use of 806 their thin sections of the Nojima Fault Zone. M. Düggelin has provid ed photographs for

807 Figures 9a and b. ZMB Basel and O. Romeyer at Savoie University in Chambéry are thanked 808 for the use of their electron microscope facilities. We are grateful to M. Boettcher and J.

809 Hazidadeh for very constructive comments, which have improved the paper. Financial

810 support for Nynke Keulen by Swiss National Fond grants nrs. 200020-100616 and 200020811108082 is gratefully acknowledged.

812 


\section{References}

Amitrano, D., Schmittbuhl, J., 2002. Fracture roughness and gouge distribution of a granite shear band. Journal of Geophysical Research 107, 2375-2390.

An, L.-J., Sammis, C., 1994. Particle size distribution of cataclastic fault materials from southern California: A 3-D study. Pure \& Applied Geophysics 143, 203-227.

Anderson, J., Osborne, R., Palmer, D., 1980. Petrogenesis of cataclastic rocks within the San Andreas Fault Zone of southern California, U.S.A. Tectonophysics 67, 221-249.

Anderson, J., Osborne, R., Palmer, D., 1983. Cataclastic rocks of the San Gabriel Fault- An expression of deformation at deeper crustal levels in the San Andreas Fault Zone. Tectonophysics 98, 209-251.

Bass, J., 1995. Elasticity of Minerals, Glasses, and Melts. In: Ahrens, T. (Ed.), Mineral Physics \& Crystallography - A handbook of Physical Constants, AGU Reference Shelf 2, 45-63.

Biegel, R., Sammis, C., Dietrich, J., 1989. The frictional properties of a simulated gouge having a fractal particle distribution. Journal of Structural Geology 11, 827-846.

Blanpied, M., Lockner, D., Byerlee, J., 1995. Frictional slip of granite at hydrothermal conditions. Journal of Geophysical Research 100, 13045-13064.

Blenkinsop, T., 1991. Cataclasis and Processes of Particle Size Reduction. Pure \& Applied Geophysics 136, 60-86.

Blenkinsop, T., Rutter, E., 1986. Cataclastic deformation of quartzite in the Moine thrust zone. Journal of Structural Geology 8, 669-681.

Bos, B., Peach, C., Spiers, C., 2000. Slip behaviour of simulated gouge-bearing faults under conditions favoring pressure solution. Journal of Geophysical Research 105, 16699-16717.

Boullier, A.-M., Fujimoto, K., Ito, H., Ohtani, T., Keulen, N., Fabbri, O., Amitrano, D., Dubois, M., Pezard, P., 2004a. Structural evolution of the Nojima Fault (Awaji Island, Japan) revisited from the GSJ drillhole at Hirabayashi. Earth Planets Space 56, 1233-1240.

Boullier, A.-M., Fujimoto, K., Ohtani, T, Roman-Ross, G., Lewin, E., Ito, H., Pezard,P. Ildefonse, B., $2004 b$. Textural evidence for recent co-seismic circulation of fluids in the Nojima fault zone, Awaji island, Japan. Tectonophysics 378, 165-181.

Byerlee, J., Brace, W., 1968. Stick slip, stable sliding, and earthquakes - effect of rock type, pressure, strain rate, and stiffness. Journal of Geophysical Research 73, 6031-6037.

Carter, N., Anderson, D., Hansen, F., Kranz, R., 1981. Creep and creep rupture of granitic rocks. In: Carter, N., Friedman, M., Logan, J., Stearns, D. (Eds.), Geophysical Monograph: Mechanical behavior of crustal rocks; the Handin volume, 24, American Geophysical Union, Washington DC, 61-62.

Chester, F., Friedman, M., Logan, J., 1985. Foliated cataclasites. Tectonophysics 111, 139-146.

Chester, J., Chester, F., Kronenberg, A., 2005. Fracture surface energy of the Punchbowl fault, San Andreas system. Nature 437, 133-136.

De Ronde, A., 2004. Mineral Reaction and Deformation in Plagioclase-Olivine Composites: An Experimental Study. PhD thesis, Basel University. 
Dor, O., Ben-Zion, Y., Rockwell, T.K. Brune, J., 2006. Pulverized rocks in the Mojave section of the San Andreas Fault Zone. Earth and Planetary Science Letters 245, 642-654.

Fabbri, O., Iwamura, K., Matsunaga, S., Coromina, G., Kanaori, Y., 2004. Distributed strike-slip faufting, block rotation, and possible intracrustal vertical decoupling in the convergent zone. In Grocott, J., Tikoff, B., McCaffrey, K., Taylor, G. (Eds.), Vertical coupling and decoupling in the litho sphere. Geological Society

Faulkner, D., Lewis, A., Rutter, E., 2003. On the internal structure and mechanics of large strike-slip fault zones: field observations of the Carboneras fault in southeastern Spain. Tectonophysics 367, 235-251.

Griggs, D., Turner, F., Heard, H., 1960. Deformation of rocks at $\mathrm{T}=500{ }^{\circ} \mathrm{C}$ to $\mathrm{T}=800{ }^{\circ} \mathrm{C}$. In Griggs, D. Handin, J. (Eds.), Geological Society of America Memoir, 79, Waverly Press, Baltimore MD, 39-104.

Hadizadeh, J., Johnson, W., 2003. Estimating local strain due to comminution in experimental cataclastic textures. Journal of Structural Geology 25, 1973-1979.

Heilbronner, R., Keulen, N., 2006. Grain size and grain shape analysis of fault rocks. Tectonophysics 427, 199216 doi:10.1016/j.tecto.2006.05.020.

Hirth, G., Tullis, J., 1994. The brittle-plastic transition in experimentally deformed quartz aggregates. Journal of Geophysical Research 99, 11731-11747.

Hoffmann, N., Schönert, K., 1971. Bruchanteil von Glaskugeln in Packungen von Fraktionen und binären Mischungen. Aufbereitungstechnik 9, 513-518.

Ito, H., Fujimoto, K., Tanaka, H., Lockner, D., 1999. Proceedings of the international workshop on the Nojima fault core and borehole data analysis, Geological Survey of Japan Interim report No. EQ/00/1, USGS Open-File Report 000-129.

Jaeger, J., 1967. Failure of rocks under tensile conditions. International Journal of Rock Mechanics and Mining Sciences 4, 219-237.

Kanamori, H., 1994. Mechanics of Earthquakes. Annual Review of Earth and Planetary Sciences 22, 207-237.

Kato, A., Ohnaka, M., Mochizuki, H., 2003. Constitutive properties for the shear failure of intact granite in seismogenic environments. Journal of Geophysical Research 108, doi:10.1029/2001JB000791.

Kendall, K., 1978. The impossibility of comminuting small particles by compression. Nature 272, 710-711.

Korvin, G., 1992. Fractal Models in the Earth Sciences. Elsevier, Amsterdam.

Lin, A., 1999. S-C cataclasite in granitic rock. Tectonophysics 304, 57-273.

Lockner, D., Summers, R., Byerlee, J., 1986. Effects of temperature and sliding rate on frictional strength of granite. Pure \& Applied Geophysics 124, 445-469.

Ma, K.-F., Tanaka, H., Song, S.-R., Wang, C.-Y., Hung, J.-H., Tsai, Y.-B., Mori, J., Song, Y.-F., Yeh, E.-C., Soh, W., Sone, H., Kuo, L.-W., Wu, H.-Y., 2006. Slip zone and energetics of a large earthquake from the Taiwan Chelungpu-fault Drilling Project. Nature 444, doi:10.1038/nature05253.

Mair, K., Frye, K., Marone, C., 2002. Influence of grain characteristics on the friction of granular shear zones. Journal of Geophysical Research 107, ECV 4-1, doi:2001JB000516.

Mandelbrot, B., 1982. The fractal Geometry of Nature. Freeman and Co., New York. 
972

973

974

975

976

Marone, C., Scholz, C., 1989. Particle-size distribution and microstructures within simulated gouge. Journal of Structural Geology 11, 799-814.

Mitra, G., 1978. Ductile deformation zones and mylonites. the mechanical processes involved in the deformation of crystalline basement rocks. American Journal of Science 278, 1057-1084.

Mitra, G., 1993. Deformation processes in brittle deformation zones in granitic basement rocks: A case study from the Torrey Creek area, Wind River Mountains. In: Schmith, C., Chase, R., Erslev, E. (Eds.), Laramide Basement Deformation in the Rocky Mountains Foreland of the Western United States. Geological Society of America Special Paper 280, 177-195.

Monzawa, N., Otsuki, K., 2003. Comminution and fluidization of granular fault materials: implications for fault slip behavior. Tectonophysics 367, 127-143.

Morgan, J., 1999. Numerical simulations of granular shear zones using the distinct element method. 2. Effects of particle size distribution and interparticle friction on mechanical behavior. Journal of Geophysical Research $104,2721-2732$.

Morgan, J., Boettcher, M., 1999. Numerical simulations of granular shear zones using the distict element method. 1. Shear zone kinematics and the micromechanics of localization. Journal of Geophysical Research $104,2703-2719$.

Morrow, C., Byerlee, J., 1989. Experimental stu dies of compaction and dilatancy during frictional sliding on faults containing gouge. Journal of Structural Geology 11, 815-826.

Murakami, M., Tagami, T., 2004. Dating pseudotachylyte of the Nojima fault using the zircon fission-track method. Geophysical Research Letters 31, doi:10.1029/2004GL020211.

Murakami, M., Tagami, T., Hasebe, N., 2002. Ancient thermal anomaly of an active fault system: zircon fission-track evidence from Nojima GSJ 750m borehole samples. Geophysical Research Letters 29, doi:10.1029/2002GL015679.

Murata, A., Takemura, K., Miyata, T., Lin, A., 2001. Quarternary vertical offset and average slip rate of the Nojima Fault on Awaji Island, Japan. The Island Arc 10,360-367.

Ohtani, T., Fujimo to, K., Ito, H., Tanaka, H ., Tomida, N., Higuchi T., 2000. Fault rocks and past to recent fluid characteristics from the borehole survey of the Nojima fault ruptured in the 1995 Kobe earthquake, southwest Japan. Journal of Geophysical Research 105, 16161-16172.

Olgaard, D., Brace, W., 1983. The micro structure of gouge from a mining-induced seismic shear zone. International Journal of Rock Mechanics and Mining Science \& Geomechanical Abstracts 20, 11-19.

Otsuki, K., Monzawa, N., Nagase, T., 2003. Fluidization and melting of go uge during seismic slip: Identification in the Nojima fault zone and implications for focal earthquake mechanisms. Journal of Geophysical Research 108, ESE 4-1-4-18.

Pittarello, L., Di Toro, G., Bizzarri, A., Hadizadeh, J., Pennacchioni, G., 2006. Seismic energy partitioning inferred from pseu dotachylyte-bearing faults (Gole Larghe Fault, Adamello batholith, Italy). EGU, Vienna. Geophysical Research Abstracts 8, EGU06-A-01883.

Prasher, C., (1987). Crushing and Grinding Process Handbook. Wiley, New York.

Reches, Z., Dewers, T., 2005. Gouge formation by dynamic pulverization during earthquake rupture. Earth and Planetary Science Letters 235, 361-374. 
Sammis, C., Biegel, R., 1989. Fractals, fault-gouge, and friction. Pure \& Applied Geophysics 131, 255-271.

Sammis, C., King, G., Biegel, R., 1987. The kinematics of gouge deformation. Pure \& Applied Geophysics $125,777-812$.

Sammis, C., Osborne, R., Anderson, J., Banerdt, M., White, P., 1986. Self-similar cataclasis in the formation of gouge. Pure \& Applied Geophysics 124, 53-78.

Schmid, S., Handy, M., 1991. Towards a genetic classification of fault rocks: Geological usage and tectonophysical implications. In: Müller, D., McKenzie, J., Weissert, H. (Eds.), Controversies in Modern Geology, Academic Press, London, 339-361.

Shao, S.-M., Zou, J.-C., 1996. Fractal research of gouge. Acta Seismologica Sinica 9, 485-491.

Sibson, R., 1977. Fault rocks and fault mechanisms. Journal of the Geological Society of London 133, 191213.

Stesky, R., Brace, W., Riley, D., Robin, P.-Y., 1974. Friction in faulted rock at high temperature and pressure. Tectonophysics 23, 177-203.

Stewart, M., Holdsworth, R., Strachan, R., 2000. Deformation processes and weakening mechansms within the frictional-viscous transition zone of major crustal-scale faults: insights from the Great Glen fault zone, Scotland. Journal of Structural Geology 22, 543-560.

Storti, F., Billi, A., Salvini, F., 2003. Particle size distributions in natural carbonate fault rocks; insights for non-self-similar cataclasis. Earth and Planetary Science Letters 206, 173-186.

Tanaka, H., Fujimoto, K., Ohtani, T., Ito H., 2000. Structural and chemical characterization of shear zones in the freshly activated Nojima fault, Awaji Island, southwest Japan. Journal of Geophysical Research 106, 8789$8810,10.1029 / 2000 J B 900444$.

Tullis, J., Yund, R., 1977. Experimental deformation of dry Westerly Granite. Journal of Geophysical Research $82,5705-5718$.

Tullis, J., Yund, R., 1980. Hydrolytic weakening of experimentally deformed Westerly Granite and Hale Albite rock. Journal of Structural Geology 2, 439-451.

Tullis, J., Yund, R., 1987. Transition from cataclastic flow to dislocation creep of feldspar: Mechanisms and microstructures. Geology 15, 606-609.

Tullis, J., Yund, R., 1992. The brittle-ductile transion in feldspar aggregates: An experimental study. In: Evans, B., Wong, T.-f. (Eds.), Fault Mechanics and transport properties of Rocks, Academic Press, San Diego, 89117.

Tullis, T., Tullis, J., 1986. Experimental rock deformation techniques. In: Hobbs, B. Heard, H. (Eds.), AGU Geophysical Monograph, Mineral and rock deformation: Laboratory Studies - The Paterson Volume 36, 297324.

Turcotte, D., (1992). Fractals and chaos in geology and geophysics. University Press, Cambridge.

Ventakaraman, A., Kanamori, H., 1992. Observational constraints on the fracture energy of subduction zone earthquakes. Journal of Geophysical Research 109, B05302, doi:10.1029/2003 JB002549.

White, S., 1982. Fault rocks of the Moine thrust zone: a guide to their nomenclature. Textures and 
1032

1033

1034

1035

1036

1037

1038

1039

1040

1041

1042

1043

1044

1045

1046

1047

1048

1049

1050

1051

1052

1053

1054

1055

1056

1057

1058

1059

1060

1061

1062

1063

1064

1065

1066

1067

1068

1069

1070

1071

microstructures 4, 211-221.

Wibberley, C., Shimamoto, T., 2005. Earthquake slip weakening and asperities explained by thermal pressurisation. Nature 436, 689-692.

Wilson, B., Dewers, T., Reches, Z., Brune, J., 2005. Particle size and energetics of gouge from earthquake rupture zones. Nature 434, 749-752.

Wilson, J., Chester, J., Chester, F., 2003. Microfracture analysis of fault growth and wear processes, Punchbowl Fault, San Andreas system, California. Journal of Stru ctural Geology 25, 1855-1873.

Wise, D., Dunn, D., Engelder, J., Geiser, P., Hatcher, R., Kish, S., Odom, A., Schamel, S., 1984. Fault-related rocks: Suggestions for terminology. Geology 12, 391-394.

Yund, R., Blanpied, M., Tullis, T., Weeks, J., 1990. Amorphous material in high strain experimental gouge. Journal of Geophysical Research 95, 15589-15602.

\section{Figure captions \& Table captions}

Figure 1:

Starting material for experiments and natural fault rocks used in study.

(a) Undeformed sample material from the Val Verzasca, Switzerland; scanning electron micrographs, back scatter contrast. This gneiss is iso tropic at the scale of a thin section and has a granite composition. $\mathrm{L}=$ lineation. Minerals, in order of increasing brightn ess: quartz (Qtz), Na-rich plagioclase (Plg), muscovite (Musc), K-feldspar (Kfs), biotite (Bt).

(b) Map of the northern part of Awaji Island, Japan, showing the locality of the Hirabayashi drill site in the Nojima Fault [after Ohtani et al. (2000)]. Inset shows the cities Tokyo and Kobe (stars) and the en larged area (black square).

(c, d) Fault rocks of the Nojima Fault Zone (recent event); scanning electron micrographs, back scatter contrast. (c) Gouge with rounded siderite fragments (white arrows) and pseudotachylyte fragment (black arrow). $623.50 \mathrm{~m}$ depth. (d) Cracked grains: individual parts can still be fitted together. The white arrow indicates siderite grains. $633.08 \mathrm{~m}$ depth.

\section{Figure 2:}

Schematic of procedure for grain size analysis.

(a) Starting image: gouge of Nojima Fault Zone; scanning electron micrographs, backscatter contrast. (b) Binary image. (c) Histogram of equivalent radii (1285 grains). (d) Log-log plot of frequency versus equivalent radius ( 20 bins per order of magnitude). The slope of the line fit yields the D-value. 
1072 (e) Combined log-log plot for entire range of magnification, showing two distinct average D-values

$1073\left(D_{<}\right.$and $\left.D_{>}\right)$and $r_{K}($ see text). (f) D-values versus magnification. Note that intermediate magnifications 1074 yield both $\mathrm{D}$-values $\left(\mathrm{D}_{<}\right.$and $\left.\mathrm{D}_{>}\right)$.

1075

1076

1077

1078

1079

1080

1081

1082

1083

1084

1085

1086

1087

1088

1089

1090

1091

1092

1093

1094

1095

1096

1097

1098

1099

1100

1101

1102

1103

1104

1105

Figure 3:

Mechanical data.

(a) Force versus axial shortening of samples of Verzasca Gneiss. For experimental conditions see Table 3, $\mathrm{r}-\mathrm{h}=$ room-humidity. (b) Differential stress versus axial shortening, calculated using program rigC4 (see text). For comparison, 3 experiments on Westerly Granite by Tullis and Yund (1977) are included. Since pyrophyllite or talc was used as confining medium, the true $\mathrm{P}_{\mathrm{c}^{-} \text {-values }}$ (indicated in brackets) are approx. 2/3 of the values given in the literature (see text).

Figure 4:

Maps of local variations of grain size distribution.

The radius of the Gauss-filter was 5 pixels $(=40 \mu \mathrm{m})$; for D-mapping technique, see Heilbronner \& Keulen (2006). D-values $>1.75$ indicate gouge, D-values $<1.75$ indicate cracked grains. Holes and biotite in samples are masked. Three samples are shown: $38 \mathrm{nk}$ (reference sample): $\mathrm{d}=3 \mathrm{~mm} ; 102 \mathrm{nk}$ : $\mathrm{d}=4.8 \mathrm{~mm} ; 60 \mathrm{nk}: \mathrm{d}=2.5 \mathrm{~mm}$. Fault surfaces are indicated. Scale applies to all samples.

\section{Figure 5:}

Microstructures of experimentally deformed samples of Verzasca Gneiss.

Scanning electron micrographs, backscatter contrast. Min erals, in order of increasing brightness: quartz, Na-rich plagioclase, mus covite, K-feldspar, biotite.

(a) Fault zone consisting of gouge with adjacent cracked grains (reference sample 38nk). (b)

Relatively narrow gou ge zone (sample 60nk, high confining pressure). (c) Reference sample 64nk. (d) Reference sample 38nk. (e) Reference sample 38nk. (f) Reference sample 38nk. (g) Cracked quartz grains at high magnification (high displacement sample 102nk). (h) Quartz gouge at high magnification (reference sample 38nk).

\section{Figure 6:}

Grain size distribution of experimentally deformed Verzasca Gneiss plotted in a log(frequency)$\log$ (equivalent radius) histogram. Results for quartz and feldspar are shown in separate graphs, results for cracked grains and gouge are shown with separate symbols. The frequency is normalized to 100 grains with a radius of $10 \mu \mathrm{m}$ for cracked grains and to 1000 grains with a radius of $10 \mu \mathrm{m}$ for gouge. 
1106 Note the slope change in most of the curves atr $\approx 2 \mu \mathrm{m}$. The $\mathrm{D}$-values $\left(\mathrm{D}_{<}\right.$and $\left.\mathrm{D}_{>}\right)$and the grain size

1107 at the slope change, $\mathrm{r}_{\mathrm{K}}$, are listed in the Table 4 and 5, respectively.

1108

1109 Figure 7:

1110 D-values of the gouge plotted again st magnification of analyzed images.

1111 Average D-values are indicated by the horizontal lines. Feldspar and quartz are shown separately.

1112 Analyses at 1000x and 2000x magnification yield a value for $\mathrm{D}_{<}$and $\mathrm{D}>$, because $\mathrm{r}_{\mathrm{K}}$ lies in the range

1113 of analyzed grain sizes .

1114

1115 Figure 8:

1116 Grain size distribution and D-values of the Nojima Fault Zone.

1117 (a) Grain size distribution of cracked grains and gouge (all minerals). The frequency is normalized to

1118100 grains with a radius of $10 \mu \mathrm{m}$ for cracked grains and to 1000 grains with a radius of $10 \mu \mathrm{m}$ for

1119 gouge. (b) D-values versus magnification, compiled from 9 cascades (see text). The average values

1120 per magnification are indicated with solid symbols. Overall average values for $\mathrm{D}_{<}$and $\mathrm{D}>$ are

1121 indicated by solid lines. The thin-sections used for the analyses originate from the following locations

1122 in the cores: a) HR4-1 (522.79 m), HR4-11 (633.08 m) b) HR4-11, HR2-52 (626.90 m), HR256

1123 (643.10 $\mathrm{m})$ and HR3-10 (623.46 m).

1124

1125 Figure 9:

1126 Scanning electron micrographs of the smallest grains found in gouge.

1127 (a,c) Nojima Fault Zone. (b,d) Experiment 63nk (room-humidity sample). (a,b) Secondary electron

1128 mode. (c,d) backscatter contrast mode. The pockmark structure in (a) is an effect of the carbon coating

1129 and does not show ind ividual atoms or another substructure.

1130

1131 Figure 10:

1132 Grain size, $r_{k}$, at the transition from $D_{<}$to $\mathrm{D}>$ (s lope change in GSD plots) and grind ing limit for

1133 quartz, after Steier \& Schönert (1972) in Prasher (1987). The uncertainty in the position of $r_{K}$ is \pm 0.3

$1134 \mu \mathrm{m}$.

1135

1136 


\section{Table 1:}

1138 Published data on grain size analyses of fault rocks.

1139 Method of analysis: LM = light microscope image of th in section, $\mathrm{SEM}=$ scanning electron

1140 microscope image, manual = analogue box counting, digitizer $=$ instrument for digital analysis of

1141 photomicrographs, digital = analyzed with computer, Coult.count. $=$ laser diffraction particle size

1142 analysis. The indicated fractal dimension (D-value) is for 2-dimensional analysis. S.A.F. = San

1143 Andreas Fault, R.S.A. = Republic of South Africa.

1144

1145 Table 2:

1146 Abbreviations and definitions of measurements as used in this paper.

Table 3:

Deformation conditions of the experiments on Verzasca gneiss.

$\mathrm{T}=$ temperature, $\mathrm{P}_{\mathrm{c}}=$ confining pressure, ${ }^{\cdot} \mathrm{e}=$ axial shortening rate rate, $\mathrm{L}_{0}=$ starting length of sample; $d_{\text {chart }}=$ axial displacement from chart strip, $\mathrm{d}_{\text {chart }-1 \mathrm{~mm}}=$ corrected axial displacement, $\mathrm{H}_{2} \mathrm{O}=$ amount of added water. Samples were quenched immediately after deformation.

1156 D-values $\left(D_{<}\right.$and $\left.D_{>}\right)$of cracked grains and gouge.

1157 In experiments, quartz and feldspar were measured separately; in natural samples (Nojima), all 1158 mineral grains were combined.

Table 5:

$1161 \mathrm{r}_{\mathrm{K}}$ values determined from grain size distributions.

1162 In experiments, the values for quartz and feldspar were determined separately; in natural samples

1163 (Nojima), all mineral grains were combined.

1164

1165

1166 


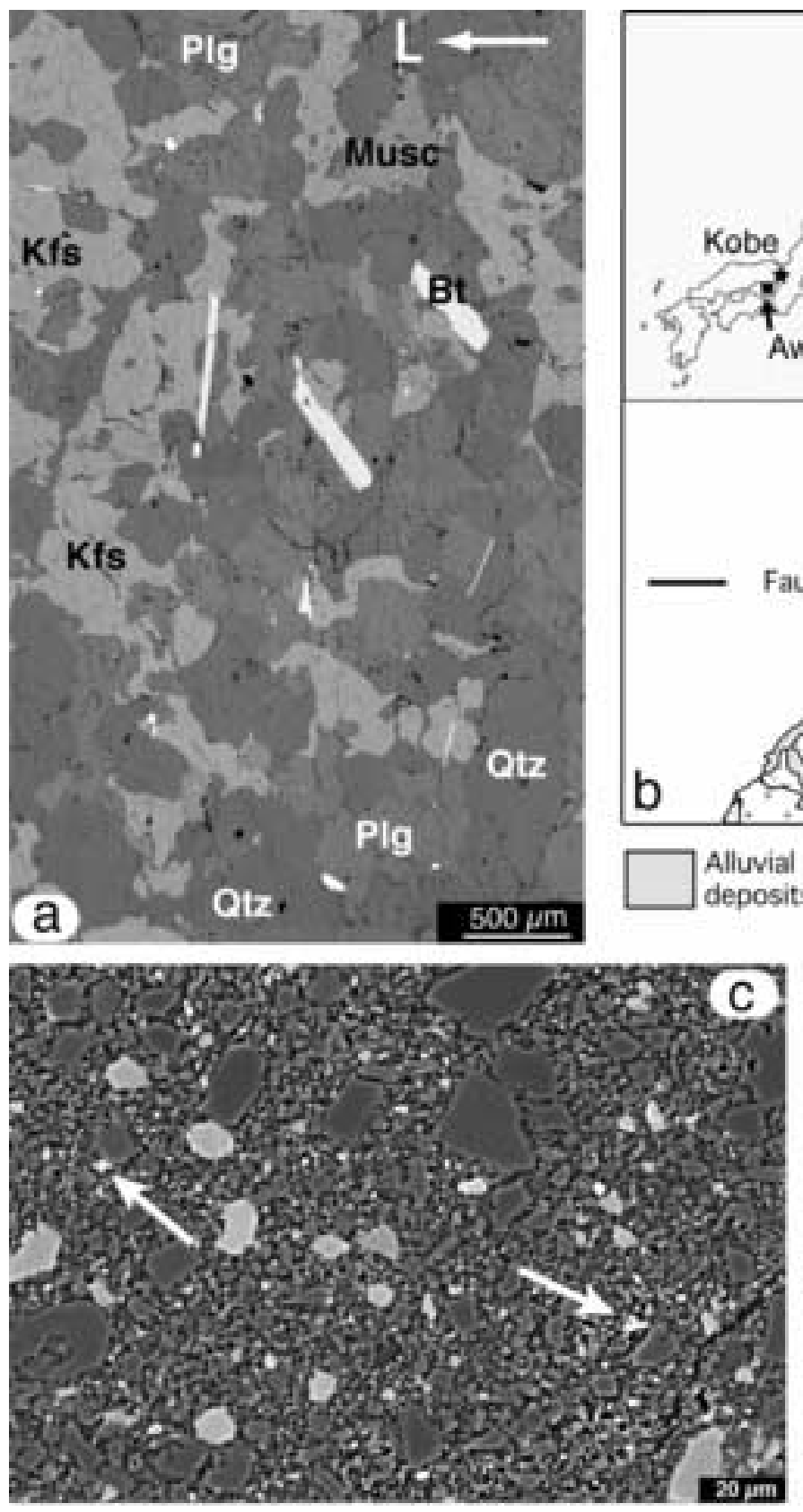

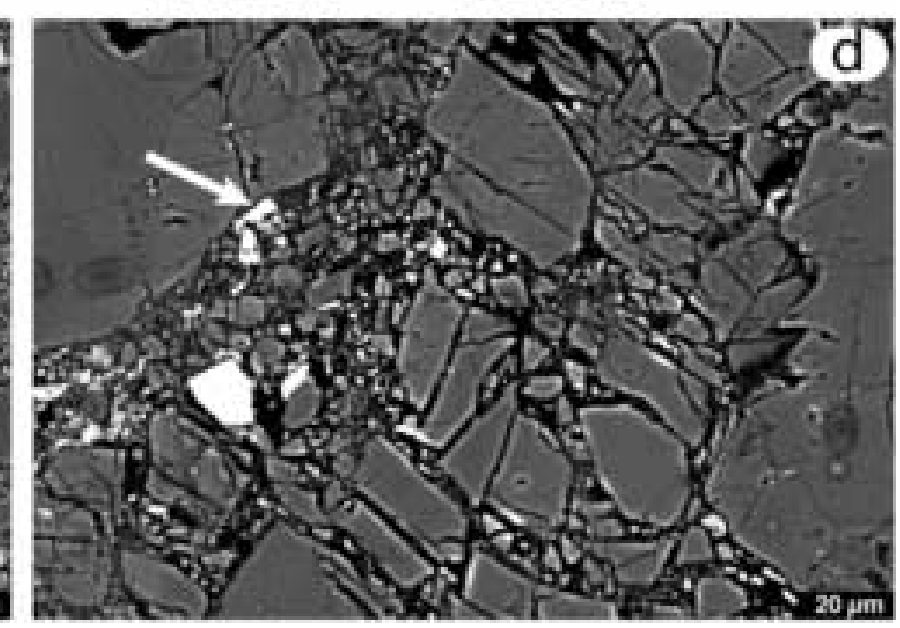

borehole

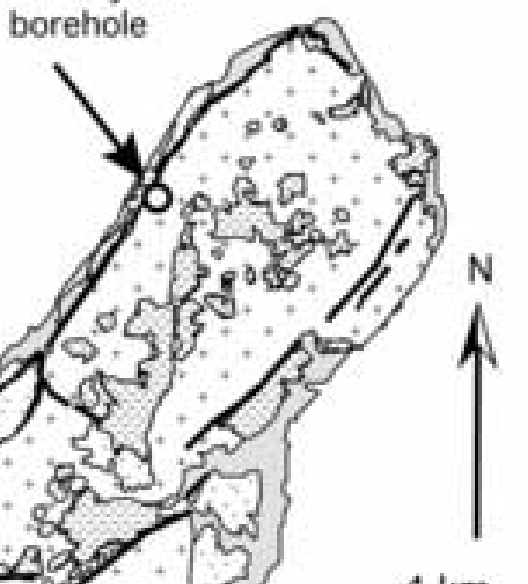

waji island
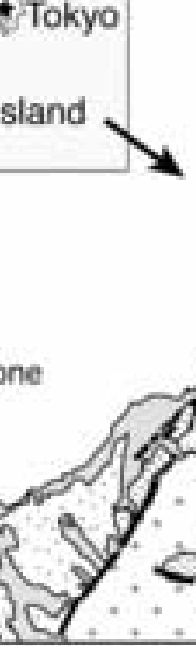

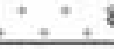

$4 \mathrm{~km}$

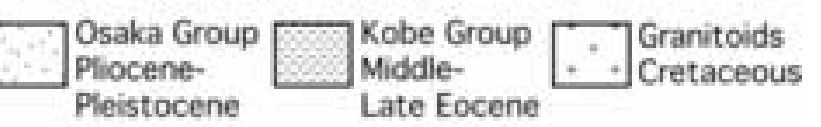



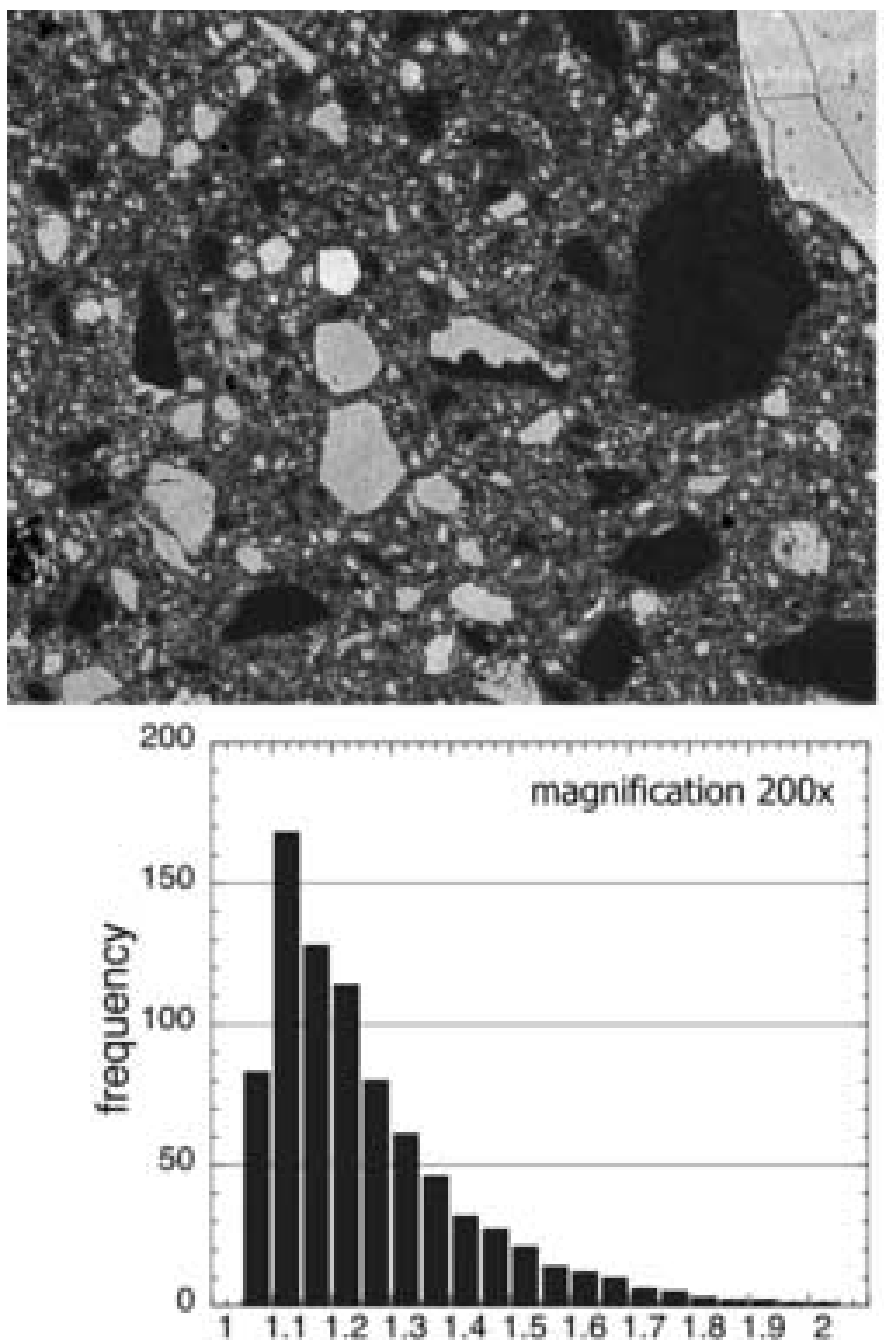

log grain size $[\mu \mathrm{m}]$

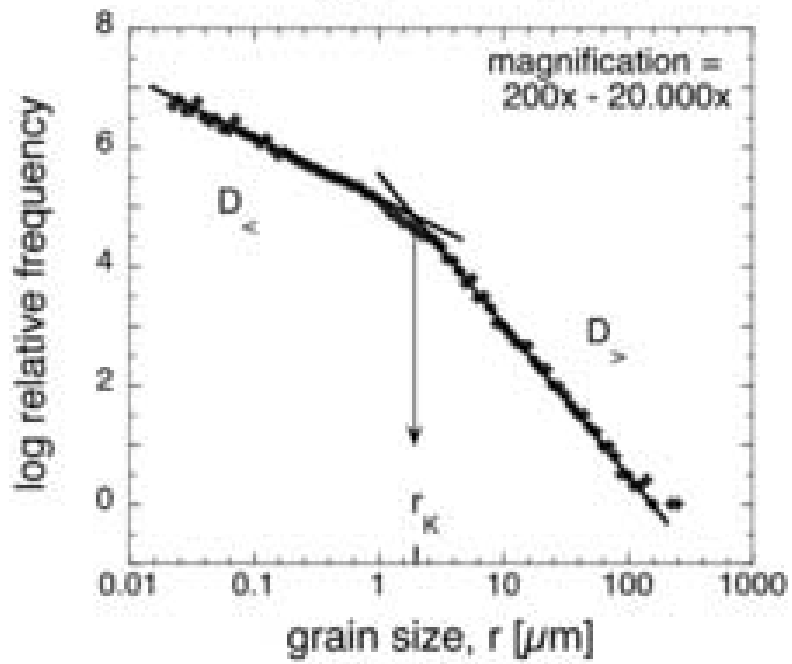

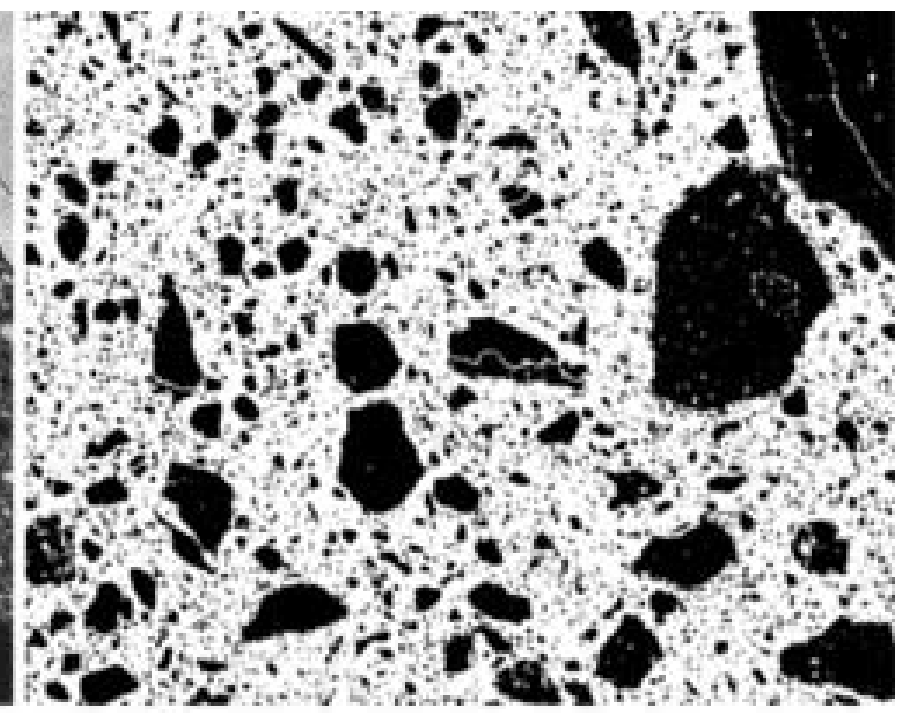
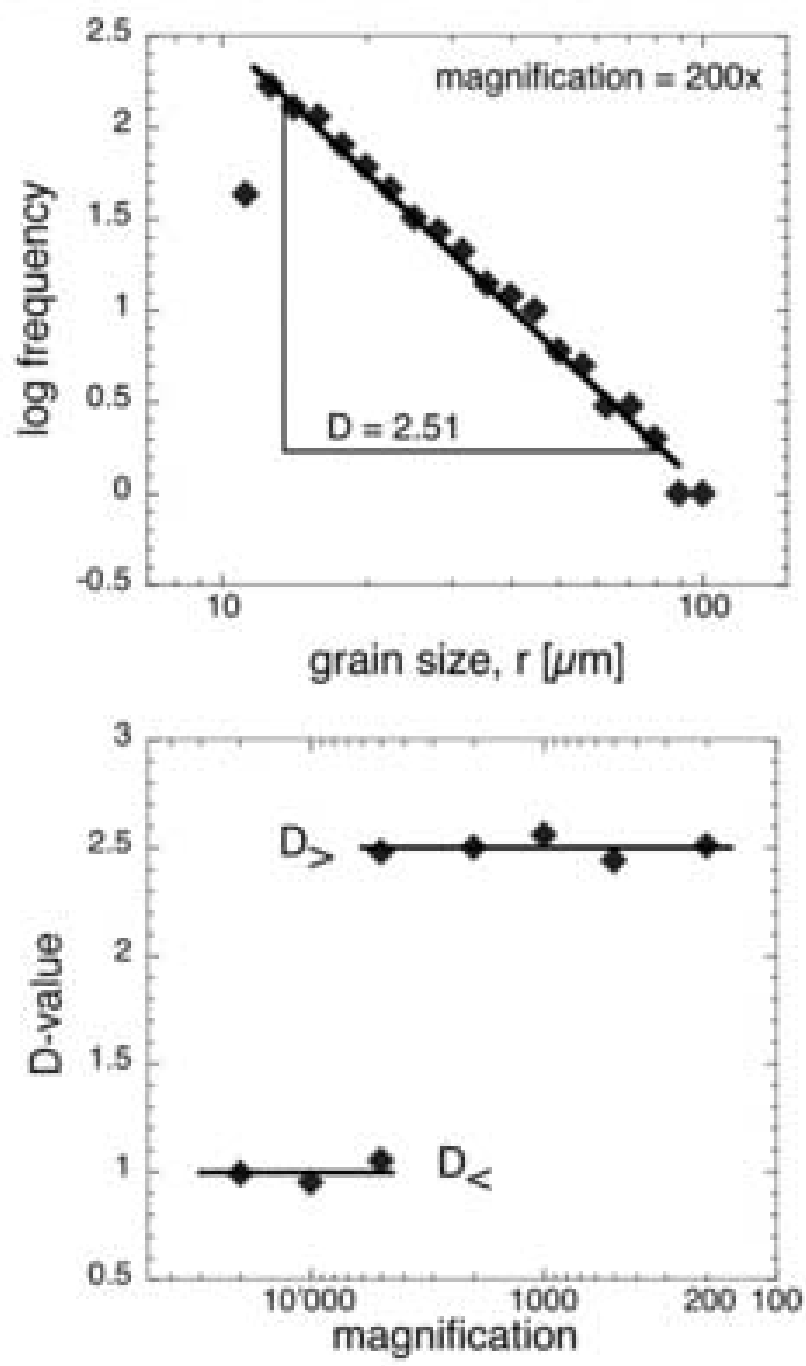
Click here to download high resolution image
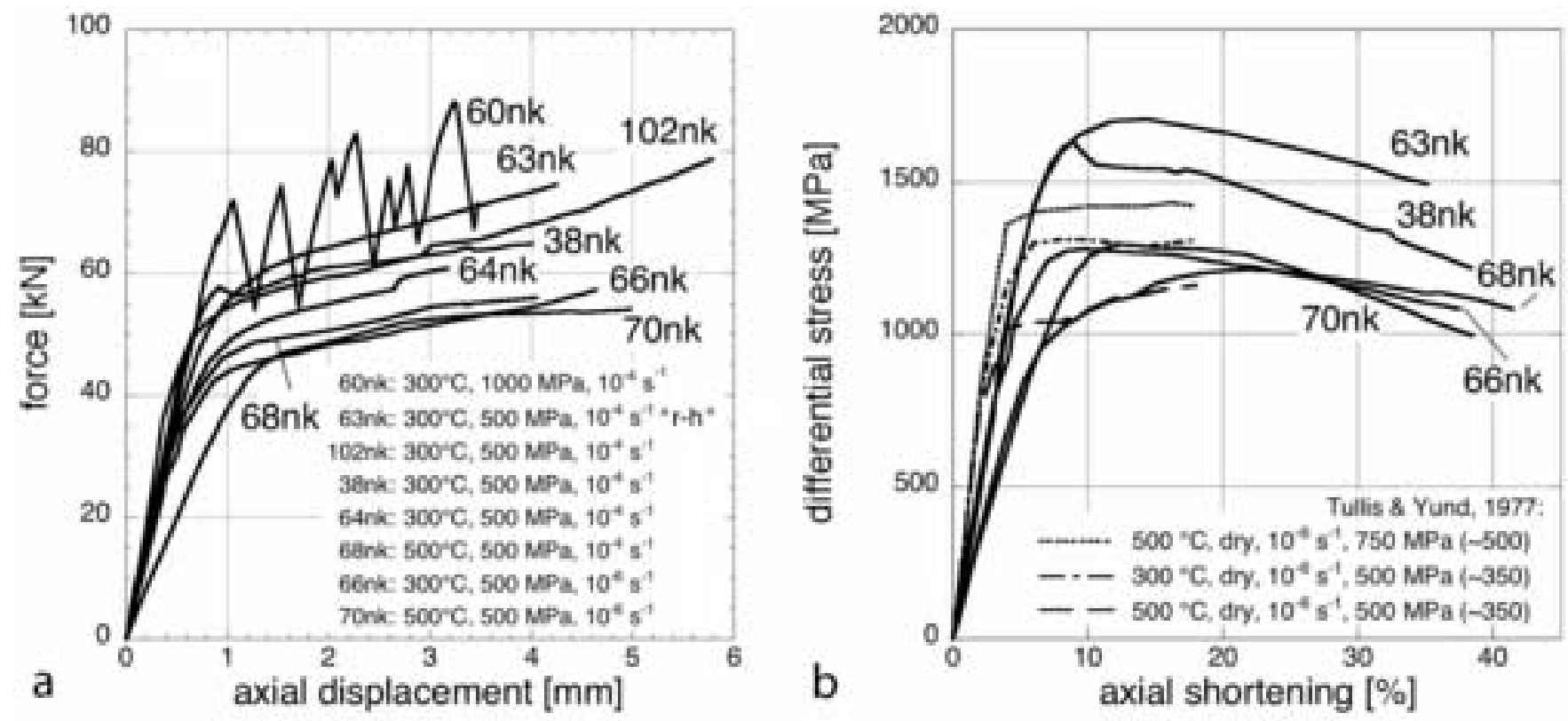

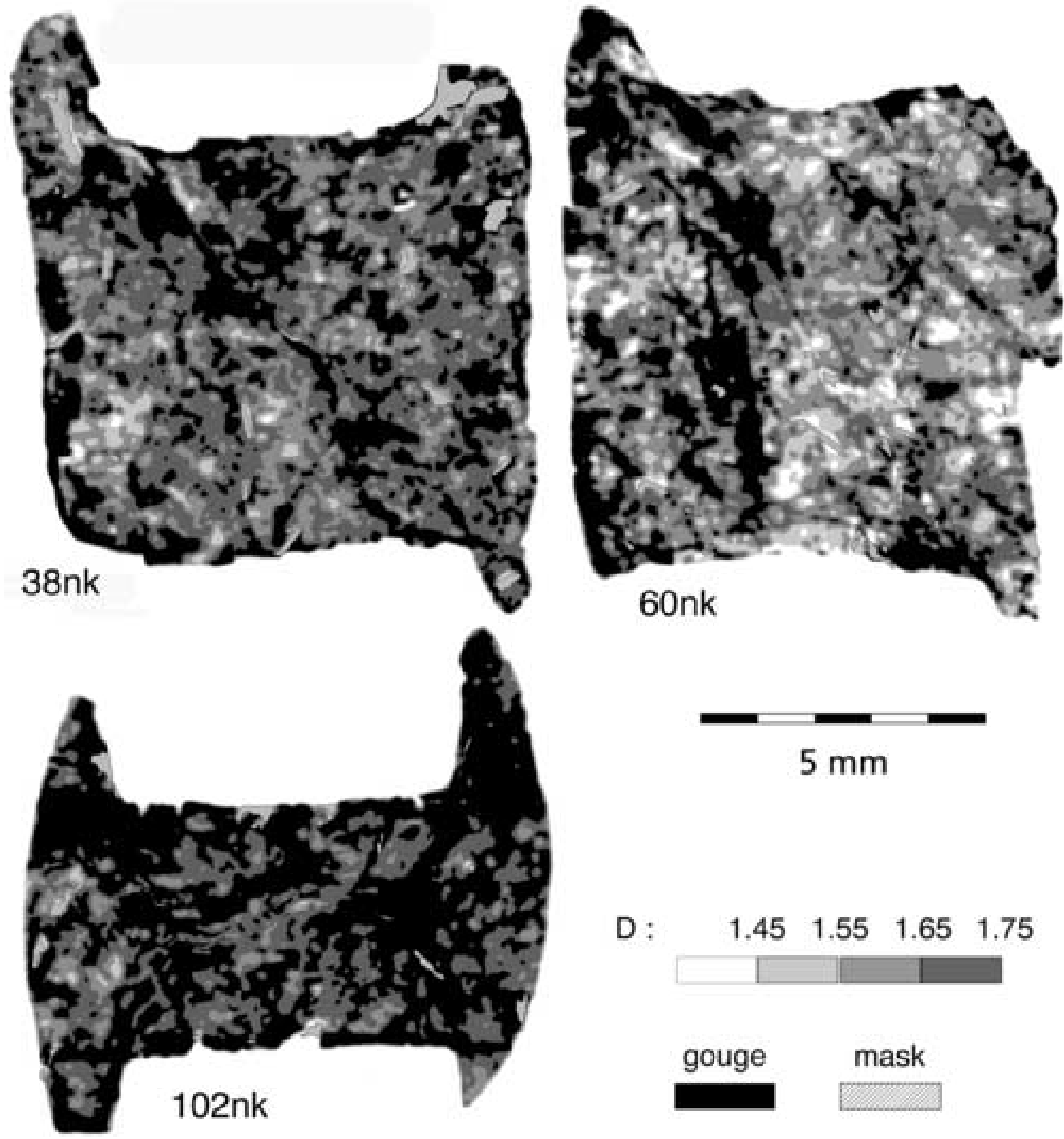

$5 \mathrm{~mm}$

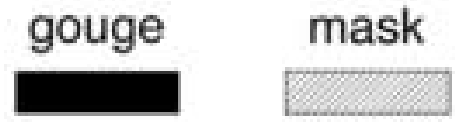



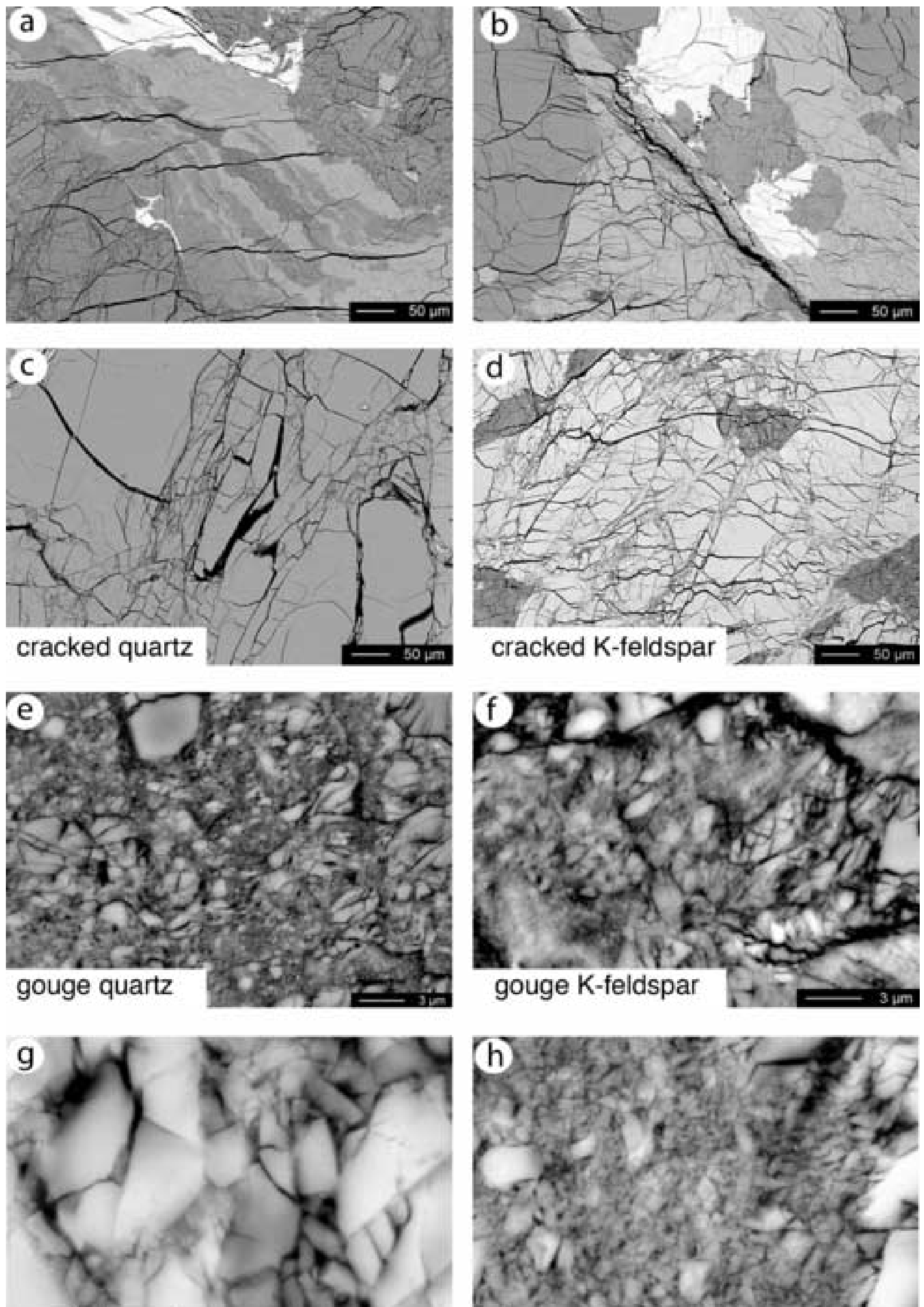

cracked quartz

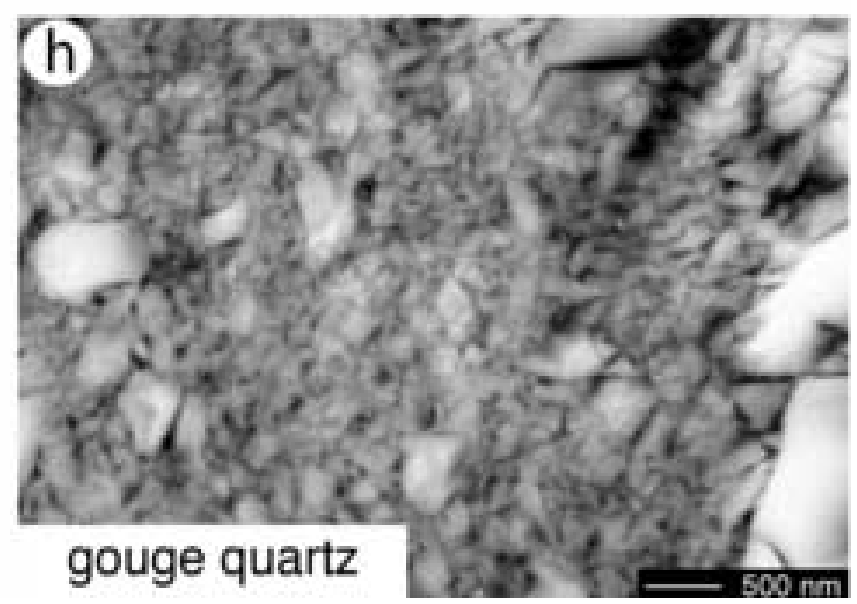


Figure06

Click here to download high resolution image

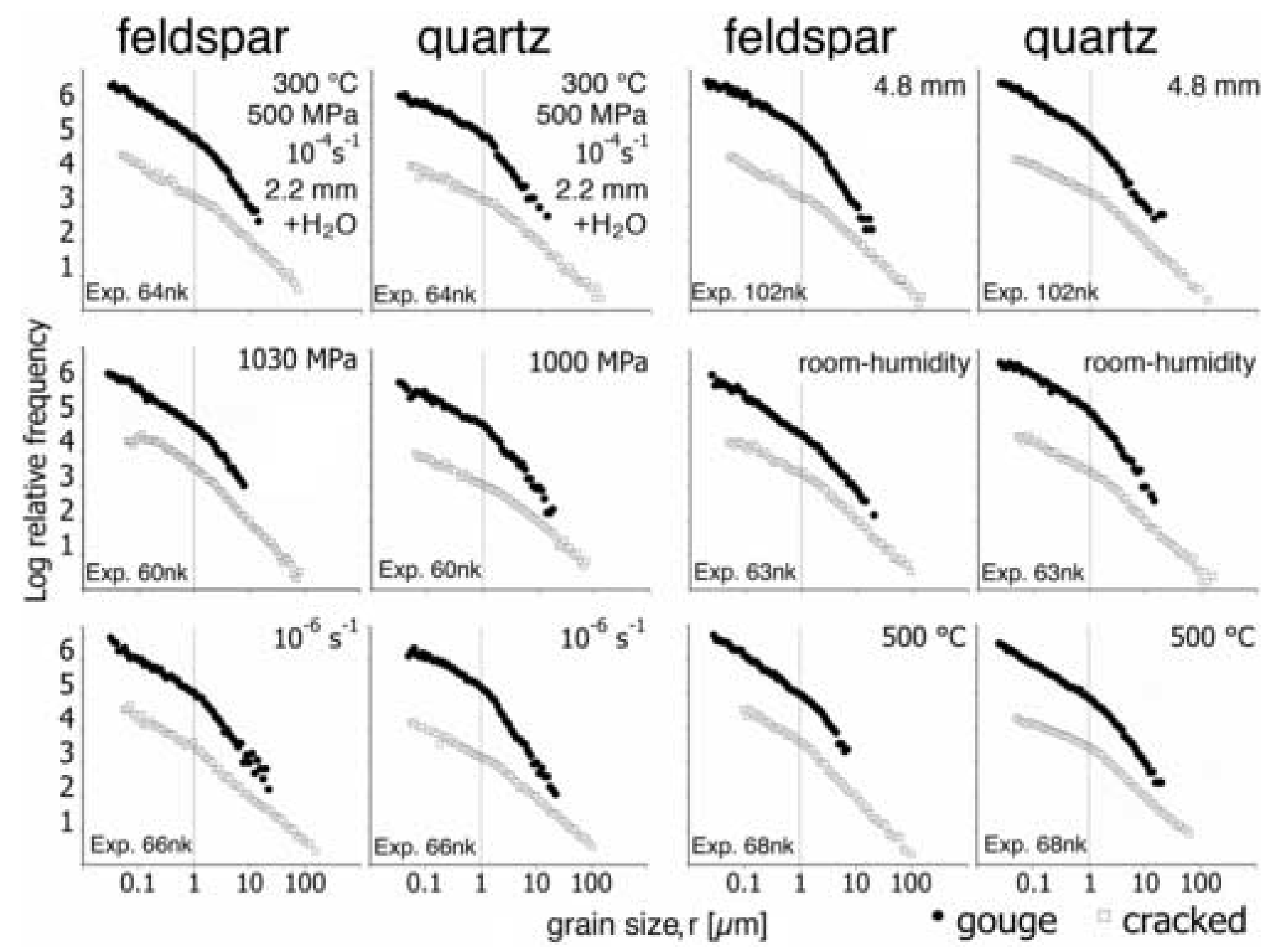



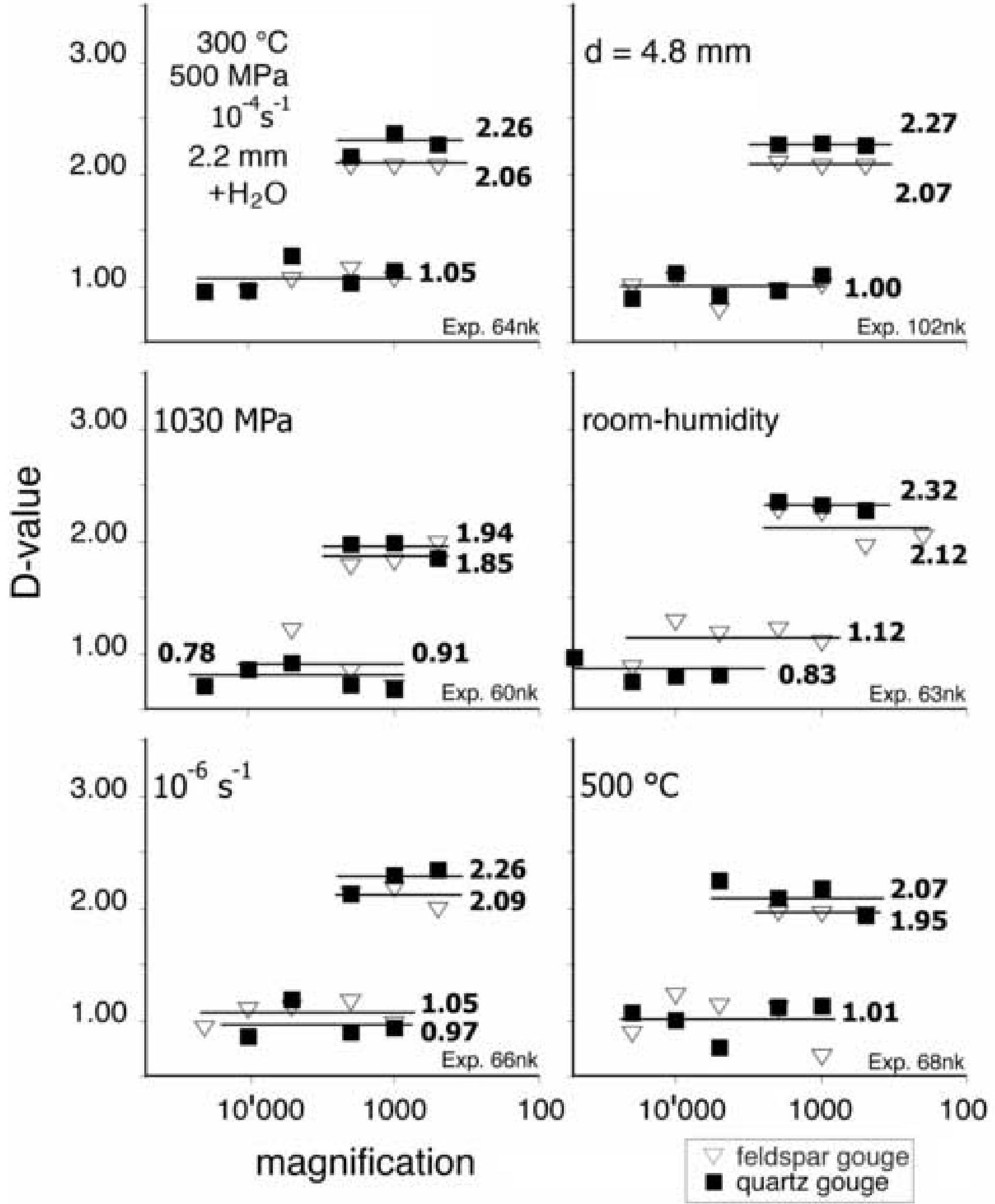

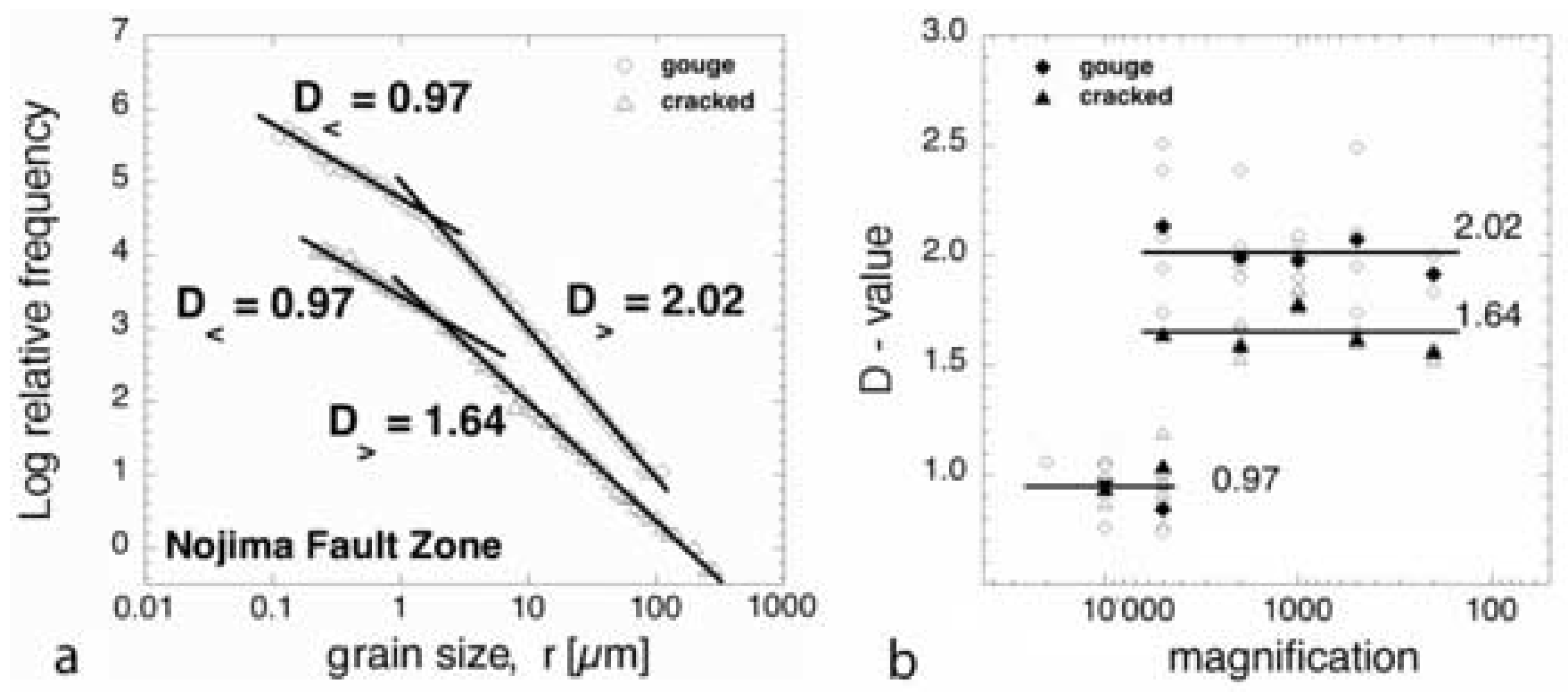
Click here to download high resolution image
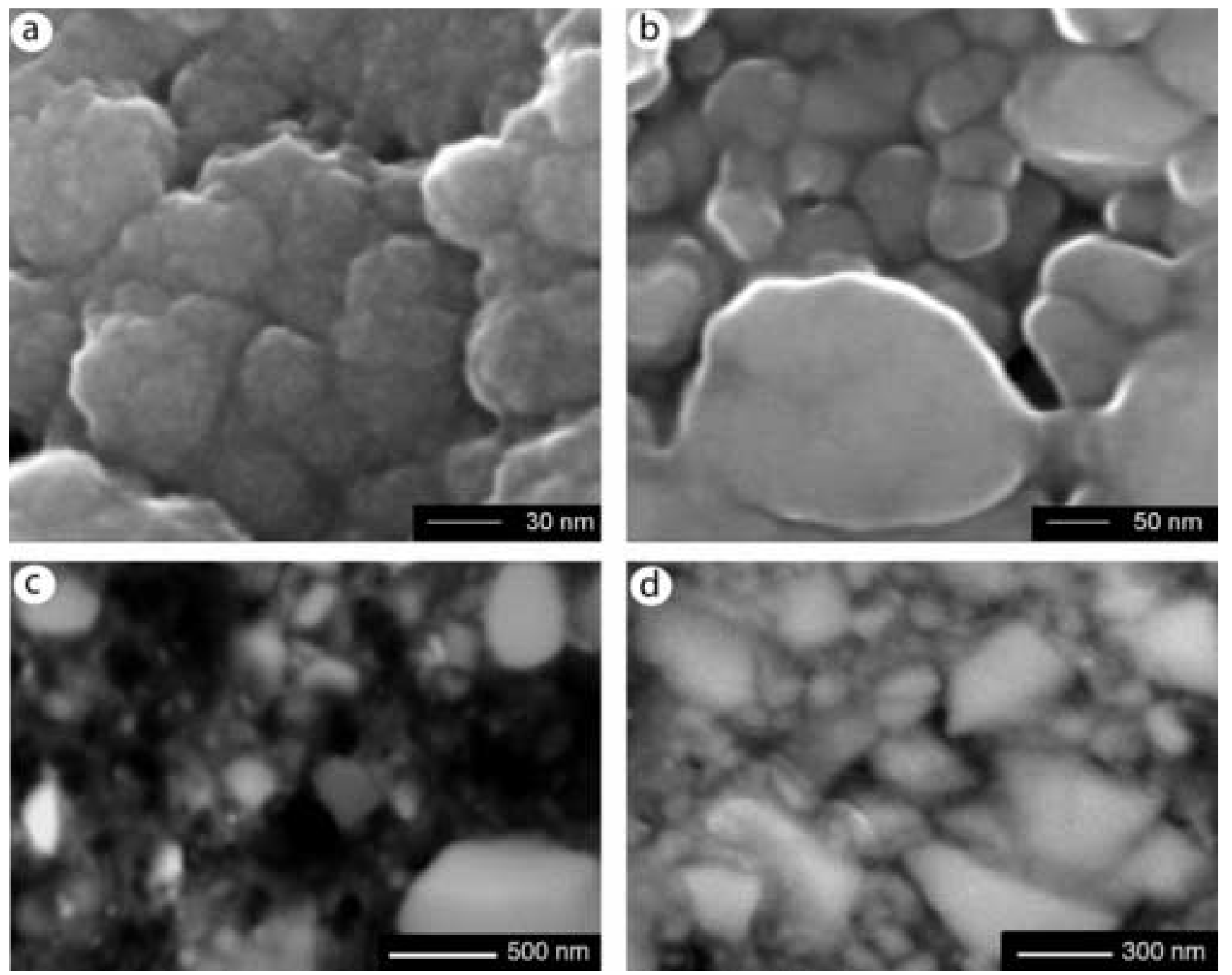


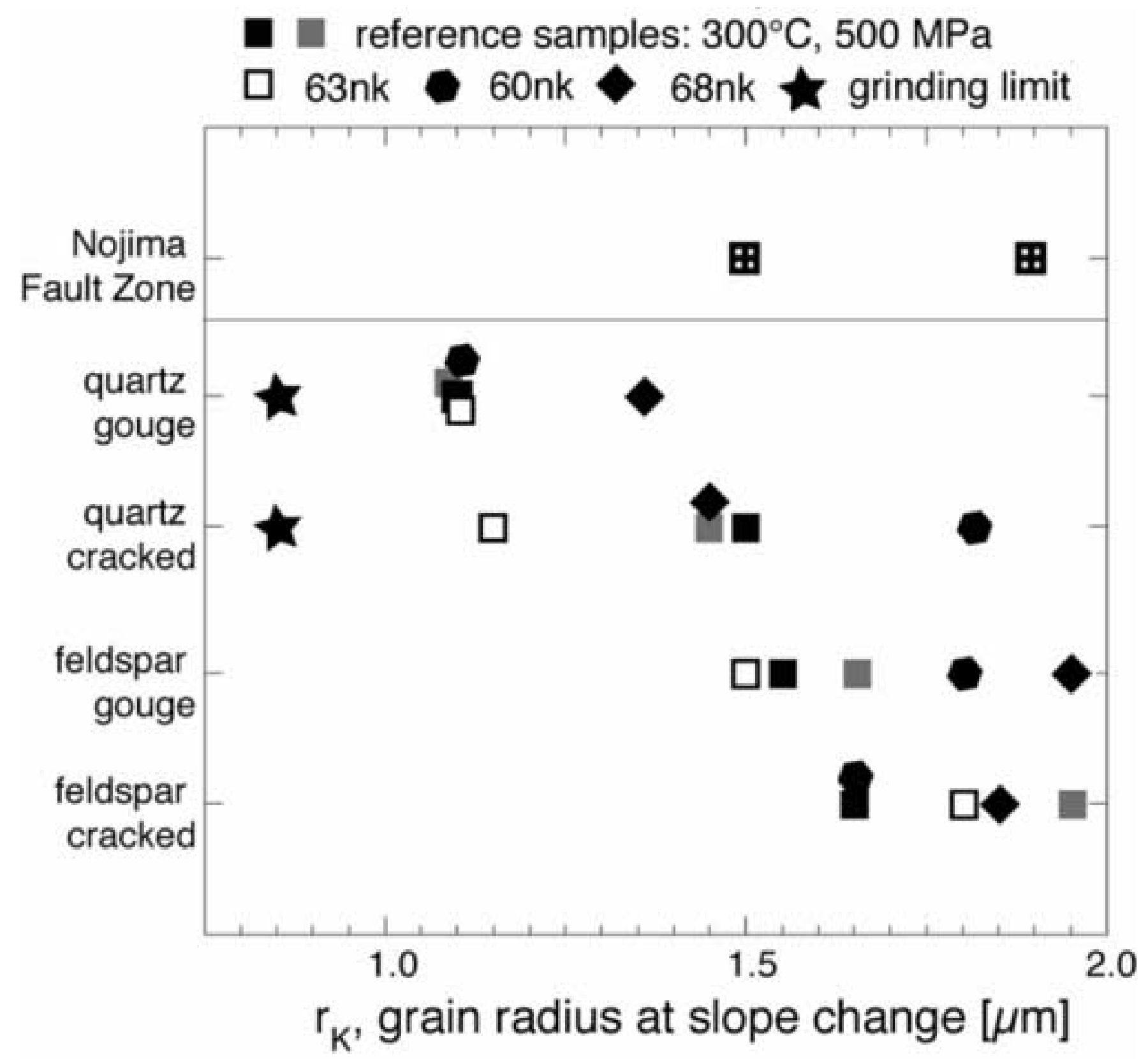

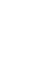

\section{- reference samples: $300^{\circ} \mathrm{C}, 500 \mathrm{MPa}$ \\ ․ $63 \mathrm{nk}$ 60nk $68 \mathrm{nk} \boldsymbol{\wedge}$ grinding limit} 0

${ }{ }^{\prime}$, grain radius at slope change $[\mu \mathrm{m}]$

ault Zone 


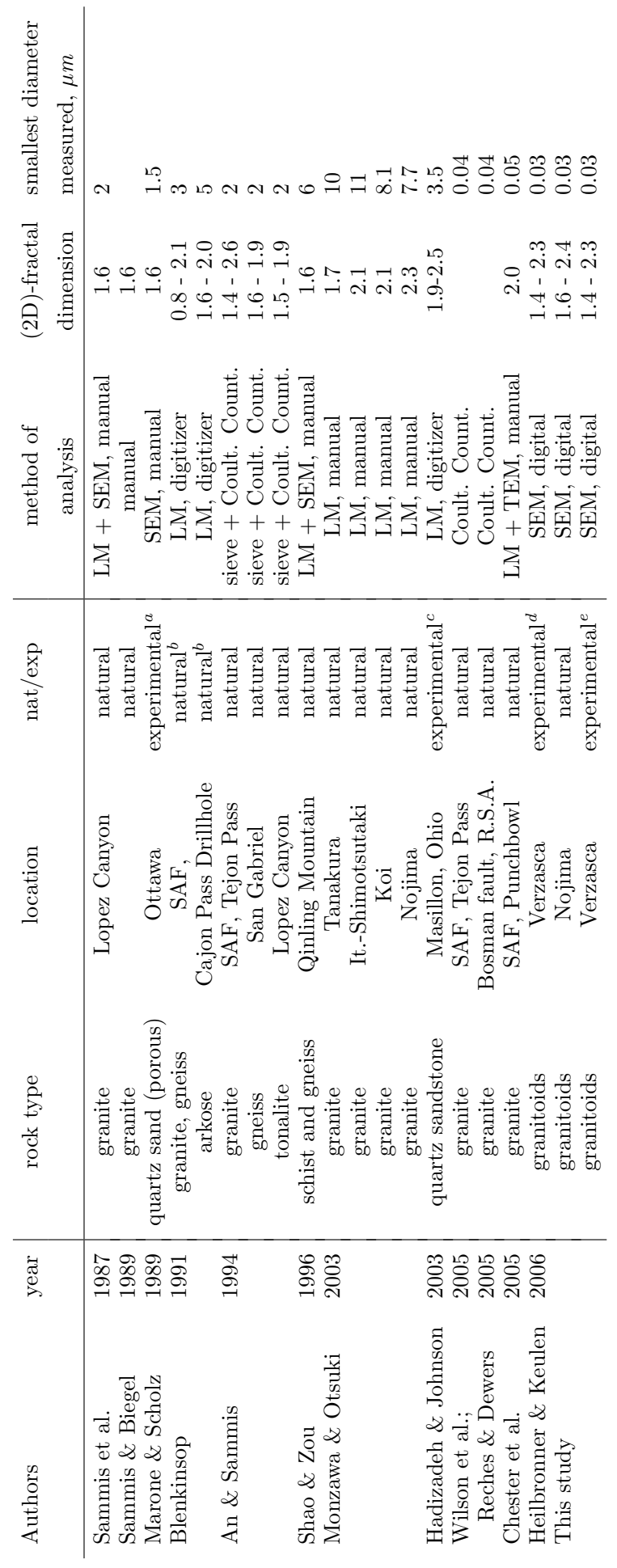

Table 1: 
Symbol Definition

$\mathrm{D}_{<} \quad$ slope of power law fit for small grain sizes $\left(\mathrm{r}<\mathrm{r}_{K}\right)$

$\mathrm{D}_{>} \quad$ slope of power law fit for large grain sizes $\left(\mathrm{r}>\mathrm{r}_{K}\right)$

$\mathrm{r}_{K} \quad$ radius of grains at slope break of GSD

$\mathrm{L}_{0} \quad$ original length of sample

$\Delta_{L} \quad$ axial shortening of sample

$\mathrm{r}_{\text {min }} \quad$ minimum grain size used for calculation of GSD

$\mathrm{r}_{\max } \quad$ maximum grain size used for calculation of GSD

A cross sectional area of grain $\left(\right.$ pixel $\left.^{2}\right)$

$\mathrm{P} \quad$ perimeter of cross section of grain (pixel)

Table 2: 
Deformation conditions

\begin{tabular}{c|ccccccc}
\hline sample nr. & $\begin{array}{c}T \\
{ }^{\circ} \mathrm{C}\end{array}$ & $\begin{array}{c}P_{c} \\
M P a\end{array}$ & $\begin{array}{c}\text { ax. } 1^{-4} \\
s^{-1}\end{array}$ & $\begin{array}{c}L_{0} \\
m m\end{array}$ & $\begin{array}{c}d_{\text {chart }} \\
m m\end{array}$ & $\begin{array}{c}d_{(\text {chart }-1 m m)} \\
\% w t\end{array}$ & $\mathrm{H}_{2} \mathrm{O}$ \\
\hline $38 \mathrm{nk}$ & 300 & 510 & 1.5 & 10.44 & 4.01 & 3.0 & 0.2 \\
$64 \mathrm{nk}$ & 300 & 500 & 1.3 & 12.33 & 3.18 & 2.2 & 0.2 \\
$102 \mathrm{nk}$ & 300 & 510 & 1.3 & 10.17 & 5.78 & 4.8 & 0.2 \\
$60 \mathrm{nk}$ & 300 & 1030 & 1.5 & 10.13 & 3.47 & 2.5 & 0.2 \\
$68 \mathrm{nk}$ & 500 & 520 & 1.4 & 10.32 & 4.28 & 3.3 & 0.2 \\
$63 \mathrm{nk}$ & 300 & 530 & 1.4 & 12.11 & 4.25 & 3.3 & 0.0 \\
$66 \mathrm{nk}$ & 300 & 490 & 0.015 & 12.37 & 4.64 & 3.6 & 0.2 \\
$70 \mathrm{nk}$ & 500 & 500 & 0.013 & 12.95 & 4.97 & 4.0 & 0.2 \\
\hline
\end{tabular}

Table 3: 
$D$-values for cracked grains and gouge

\begin{tabular}{|c|c|c|c|c|c|c|c|c|}
\hline \multirow[b]{3}{*}{ sample nr. } & \multicolumn{4}{|c|}{ feldspar } & \multicolumn{4}{|c|}{ quartz } \\
\hline & \multicolumn{2}{|c|}{ cracked } & \multicolumn{2}{|c|}{ gouge } & \multicolumn{2}{|c|}{ cracked } & \multicolumn{2}{|c|}{ gouge } \\
\hline & $D_{<}$ & $D_{>}$ & $D_{<}$ & $D_{>}$ & $D_{<}$ & $D_{>}$ & $D_{<}$ & $D_{>}$ \\
\hline $38 \mathrm{nk}$ & 1.02 & 1.68 & 1.00 & 2.03 & 1.09 & 1.56 & 1.10 & 2.26 \\
\hline $64 \mathrm{nk}$ & 0.95 & 1.52 & 1.05 & 2.06 & 0.74 & 1.44 & 1.05 & 2.26 \\
\hline $102 \mathrm{nk}$ & 0.87 & 1.52 & 1.01 & 2.07 & 0.92 & 1.55 & 1.00 & 2.27 \\
\hline $60 \mathrm{nk}$ & 0.74 & 1.37 & 0.91 & 1.85 & 0.96 & 1.72 & 0.78 & 1.94 \\
\hline $68 \mathrm{nk}$ & 0.92 & 1.67 & 1.01 & 1.95 & 0.92 & 1.47 & 1.01 & 2.07 \\
\hline $63 \mathrm{nk}$ & 0.72 & 1.62 & 1.12 & 2.12 & 0.78 & 1.55 & 0.83 & 2.32 \\
\hline \multirow[t]{3}{*}{$66 \mathrm{nk}$} & 0.86 & 1.37 & 1.05 & 2.09 & 0.96 & 1.46 & 0.97 & 2.26 \\
\hline & \multicolumn{4}{|c|}{$\begin{array}{c}\text { Nojima Fault Zone } \\
\text { cracked gouge }\end{array}$} & & & & \\
\hline & $\begin{array}{c}D_{<} \\
0.97\end{array}$ & $\begin{array}{c}D_{>} \\
1.64\end{array}$ & $\begin{array}{c}D_{<} \\
0.97\end{array}$ & $\begin{array}{c}D_{>} \\
2.02\end{array}$ & & & & \\
\hline
\end{tabular}

Table 4: 
$r_{K}$ : Grain radius at slope change $[\mu \mathrm{m}]$

\begin{tabular}{|c|c|c|c|c|c|c|c|c|}
\hline \multirow[b]{3}{*}{ sample nr. } & \multicolumn{4}{|c|}{ feldspar } & \multicolumn{4}{|c|}{ quartz } \\
\hline & \multicolumn{2}{|c|}{ cracked } & \multicolumn{2}{|c|}{ gouge } & \multicolumn{2}{|c|}{ cracked } & \multicolumn{2}{|c|}{ gouge } \\
\hline & $r_{K}$ & range & $r_{K}$ & range & $r_{K}$ & range & $r_{K}$ & range \\
\hline $38 \mathrm{nk}$ & 1.6 & $1.4-1.7$ & 1.5 & $1.4-1.7$ & 1.5 & $1.3-1.6$ & 1.1 & $0.9-1.1$ \\
\hline $64 \mathrm{nk}$ & 1.9 & $1.7-2.0$ & 1.6 & $1.5-1.7$ & 1.3 & $1.2-1.4$ & 1.1 & $1.0-1.3$ \\
\hline $102 \mathrm{nk}$ & 1.8 & $1.7-2.0$ & 1.5 & $1.3-1.7$ & 1.4 & $1.4-1.5$ & 1.1 & $0.9-1.1$ \\
\hline $60 \mathrm{nk}$ & 1.7 & $1.6-1.7$ & 1.8 & $1.6-1.9$ & 1.8 & $1.8-2.0$ & 1.1 & $1.0-1.2$ \\
\hline $68 \mathrm{nk}$ & 1.8 & $1.6-1.9$ & 1.9 & $1.9-2.0$ & 1.5 & $1.4-1.6$ & 1.3 & $1.3-1.5$ \\
\hline $63 \mathrm{nk}$ & 1.8 & $1.7-1.9$ & 1.5 & $1.5-1.6$ & 1.1 & $1.1-1.3$ & 1.1 & $1.0-1.3$ \\
\hline \multirow[t]{4}{*}{$66 \mathrm{nk}$} & 1.6 & $1.3-1.6$ & 1.3 & $1.3-1.6$ & 1.8 & $1.6-1.9$ & 1.4 & $1.4-1.6$ \\
\hline & \multicolumn{4}{|c|}{$\begin{array}{l}\text { Nojima Fault Zone } \\
\text { cracked }\end{array}$} & & & & \\
\hline & & range & & range & & & & \\
\hline & 1.9 & $1.6-2.0$ & 1.5 & $1.2-1.6$ & & & & \\
\hline
\end{tabular}

Table 5: 